Article

\title{
Prevailing Approaches and Practices of Citizen Participation in Smart City Projects: Lessons from Trondheim, Norway
}

\author{
Savis Gohari ${ }^{1, *(\mathbb{D}}$, Daniela Baer ${ }^{2}$, Brita Fladvad Nielsen ${ }^{1}$, Elena Gilcher ${ }^{3}$ and \\ Welfry Zwestin Situmorang ${ }^{1}$ \\ 1 Department of Architecture and Planning, Norwegian University of Science and Technology (NTNU), \\ 7034 Trondheim, Norway; brita.nielsen@ntnu.no (B.F.N.); zwestinw@stud.ntnu.no (W.Z.S.) \\ 2 Department of Architecture, Materials and Structures, SINTEF, 7034 Trondheim, Norway; \\ daniela.baer@sintef.no \\ 3 Urban and Metropolitan Studies, Department of Geography, Faculty of Geosciences, Ruhr-Universität \\ Bochum (RUB), 44801 Bochum, Germany; elena.gilcher@rub.de \\ * Correspondence: savis.gohari@ntnu.no
}

Received: 9 March 2020; Accepted: 16 April 2020; Published: 20 April 2020

\begin{abstract}
Citizen participation has become an important aspect in the design of smart cities. This paper investigates the frame and modality of citizen participation in a European Horizon2020 smart city project, +CityxChange, in Trondheim. +CityxChange aims at enabling citizen participation and co-creation in the transition to a positive energy city. The question is "what are the prevailing approaches and practices in relation to citizen participation amongst the key actors involved in +CityxChange? Which structures and processes have inhibited or fostered the participation mechanisms (e.g., for, by, and of people) and practices in Trondheim?" Through participatory observations and interviews with key local actors and citizens, we found that the focus of +CityxChange on efficiency and creating innovative solutions "for" people in partnership with the private sector has disturbed the "by" and "of" people mechanisms of participation. Citizens' power and roles are not delegated to challenge or replace the project's predetermined issue or plan. The anchorage of the project outside of the formal administrative structure has caused other functional barriers that inhibit citizen participation, rather than facilitate it. This paper discusses the causal relationships between these interconnected barriers and suggests how authorities can possibly overcome them.
\end{abstract}

Keywords: smart city; citizen participation; legitimacy; democracy; +CityxChange; Trondheim

\section{Introduction}

Increased population, increased pollution, climate change, and limited natural resources are some of the main challenges that threaten our modern cities. The European way to tackle these challenges is to define and adopt smart city solutions at an urban level, pursuing the 2020 targets [1]. The development of smart city strategies is closely aligned to the goals and targets of the United Nation Sustainable Development Goals (SDGs). Accordingly, the EU is dedicating specific funding instruments to achieve better quality of life for citizens; more competitive industries and small and medium enterprises (SMEs); and more sustainable energy, transport and information, and communication technologies (ICT) and infrastructures [2]. One of the available EU initiatives to implement smart cities' solutions are the lighthouse projects that are financed by Horizon2020 [1]. These projects target SDG 7, which is to"(e)nsure access to affordable, reliable, sustainable and modern energy for all"; SDG 11, to "(m)ake cities inclusive, safe, resilient and sustainable"; and SDG 13, to "( $\mathrm{t}$ )ake urgent action to combat climate 
change and its impacts". Therefore, the main emphasis is on enabling citizens to actively participate in a sustainable transition which is facilitated through the technological change. In this context, the integration of different social sciences and humanities fields, as well as responsible research and an innovation approach, is of high importance [3]. This paper focuses on one of the European lighthouse smart city projects, +CityxChange, researching the citizen participation, the social-human aspect. According to +CityxChange, "(a) smart city will use digital technologies to enhance performance and wellbeing, to reduce costs and resource consumption and to engage more effectively and actively with its citizens" [4].

The remainder of this paper explores the prevailing approaches and practices in relation to citizen participation, both in theory and practice, in the early stages of +CityxChange. Section 2 first provides a short introduction to the emergence of the citizen centric into the smart city field. Then it draws on the relevant literature and existing conceptual frameworks, to address the most critical principles and values and to discuss their implications for citizen participation. Section 3 offers a detailed explanation of the method used in this research. Section 4 describes the findings and analyzes the existing participatory approaches and efforts, drawing from Trondheim's experiences. Section 5 provides some relevant suggestions, and the final section (Section 6) summarizes and synthesizes the findings, the theoretical analysis, and the implications of the findings for future studies and practices.

\section{Emergence of Citizen-Centric Approach into the Smart City}

As Giffinger, et al. [5] argue, the globalization and European integration process trailed the initial increasing pressure of competition between European cities, which have strived for a better positioning in the European or national urban system, through improving their specific urban-regional profile. Later, the European Commission introduced "smartness" to the agenda of reclaiming economic competitiveness, stressing the importance of corporate innovation and public-private partnerships [6]. Many authors, such as Schaffers, et al. [6], reassess the smart city as both a key technology domain and a complex societal phenomenon, in which effective user-driven processes of innovation are crucial for achieving socioeconomic benefits. One of the first strategies to develop user-centric innovation and smart urban areas, according to Komninos et al. [7], was to increase citizen involvement by co-creating Internet-based applications in all sectors of the economy and society. However, such strategies have been critiqued for being overly technocratic and top-down in orientation, serving the interests of governments and corporations more than they do of citizens [8,9]. In addition, the effect of participation on legitimacy through digital applications is unclear and cannot compensate for un-governability [10]. To tackle this, the European Commission has branded its funding programs as creating smart cities with a dedicated "citizen-focus" approach as a logical extension of the democratic process [9], strengthening the links between the city and its citizens and promising to empower citizens to take on a new role in their daily lives [11]. Likewise, new smart city pilots under the European Horizon2020 program are trying to reframe citizen-participation practices. The rhetoric of smart city researchers is that citizens' engagement will increase their impact by better integrating their perspectives into decision-making and design of services and infrastructure [12]. When citizens are involved in the planning process, a plan or a decision will be more widely accepted by its future users and implementation will be easier [13]. In addition, the perspectives of citizens as non-experts can (re)discover more sustainable and creative solutions that could work in a specific local context [14]. The engagement of citizens in scientific problem solving and co-design can result in more creative and cost-effective solutions than traditional research and development programs [14], in which the insights about local environment, context, and place might never have been broached or might have been forgotten $[13,15,16]$.

As Halachmi et al. [17] argue, citizen participation is an important element not only to achieve the democratic governance process but also to increase government productivity, citizen satisfaction, citizens' trust in government, and transparency to make decisions about service levels, procedures, and priorities. If one accepts that new ideas can emerge from citizen participation which might rarely enter the bounds of the planning profession and its bureaucracy, the maximization of citizens' input should be 
paramount [15]. While many scholars argue a democratic citizen-participation process is usually costly, time-consuming, and labor- and resource-intensive, some smart cities adopt "open data" resources and web-based strategies, for third parties and citizens to facilitate innovation, in which citizens can be both users and sources of data [18]. However, many, such as Nielsen, et al. [19], believe that the relative novelty of the smart city, combined with the prolific use of its concept as a buzzword [18], has led to many unproven success statements concerning citizen participation. Cardullo and Kitchin [9] (p. 2) believe that such a citizen participatory ideal appears to be a "rebranding to silence detractors and award international grants, while keeping the central mission of capital accumulation and top-down or technocratic governance intact". Nielsen et al. [19] also argue that the highly technical-oriented ambitions of smart cities have led to narrow dialogues which undermine the real power and capacity of stakeholders, including citizens to influence urban-planning outcomes. Regarding the inherently contested and problematic nature of the citizen participation (an emphasis on the technical expertise and impartiality on one hand, and democratic social and political system on the other) $[10,20]$, this paper aims to do the following:

- To empirically make sense of citizen participation and potential pitfalls within the smart city projects;

- to interrogate the framing and role of citizens in the process of developing and implementing smart initiatives.

\subsection{Conceptualization of Citizen Participation}

\subsubsection{Approaches}

\section{Participatory versus Deliberative Democracy}

The discourse of participation is commonly derived from a theoretical tension between participatory democracy and deliberative democracy [21]. On the one hand, participatory democracy aims at giving actual decision-making power to citizens. Therefore, participation becomes a tool for citizens to gain control over the decisions affecting their lives, as well as critical awareness of their conditions [22]. On the other hand, in a deliberative democracy, the focus is on deliberation, the way people trade off their interests, ideas, and arguments, rather than focusing on direct decision-making power. As Joss et al. [10] state, "public deliberation and political participation and contestation are an essential part of establishing common values and goods, which in a pluralistic society requires accommodating diverse perspectives through open deliberation rather than relying on a homogenous community containing a universal common good".

While participatory democracy focuses on the responsiveness to citizen concerns as a result of participation by the people (political participation), deliberative democracy is judged in terms of the effectiveness of policy outcomes for the people (governing effectiveness) [21,23]. In both theories, participation is assessed by democratic legitimation.

Input versus Output Legitimacy

According to Scharpf [23] (p. 7) participatory democracy refers to "input legitimacy" and implies "the participatory quality of the process, leading to laws and rules as ensured by the 'majoritarian' institutions of electoral representation". On the other hand, deliberative democracy refers to "output legitimacy", which "is concerned with the problem-solving quality of the laws and rules and has a range of institutional mechanisms to ensure it" [24]. Within smart cities projects, this discourse implies that the role of political actors is as representatives of citizens. One could investigate, for example, to what extent citizens are directly or indirectly represented, by looking at how decisions in such projects move within the formal decision-making structure of a city. 
Direct versus Indirect Participation

Falleth, et al. [25] argue that the input legitimacy of urban planning is dependent on two forms of citizen participation: voice and vote. The former implies a direct and non-parliamentarian participation as explicit empowerment perspective. The latter implies indirect participation through representative politicians. Voice or direct participation can supplement the deficiencies of majoritarian institutions of representative democracy [26]. The direct democracy is designated as the "substantive view of democracy, a normative political and societal ideal that is worth striving for as an objective in its own right" [27] (p. 120). In direct participation, democracy is a value in itself. Instead of advocating a formalized decision-making procedure, empowering citizens in policy-making is a goal, i.e., encouraging citizens to be both active and responsible [10,27].

In indirect participation or representative democracy through "vote", citizens generally play a passive role. As Wagle [28] argues, indirect participation can involve complexity because it embraces two different value systems: politicians' own values and the values of citizens [29]. While citizens' values influence public officials in choosing the agendas and designing policies, politicians' values, agenda-setting, and policy designs also influence the political orientations and participation patterns of citizens [30]. Schneider and Ingram [30] argue that it is in politicians' advantage to provide beneficial policy to the advantaged citizens who are both powerful and positively constructed as "deserving" (e.g., the elderly, business, veterans, or scientists). These groups are thought to not only respond favorably to their politicians' decisions, but others will approve of conferring the beneficial policy on deserving people. Accordingly, politicians usually identify the people whose behavior is linked to the achievement of their own values and desired ends. In other words, politicians attempt to achieve their goals by changing people's behavior and attitude [31].

Politicians' tendency to favor powerful interests is especially relevant in the discussion of smart cities. "Smartness" is often conflated with efficiency [31], which places a premium on the inclusion of actors who have proportionally greater resources, financial capabilities, technical knowledge, and competences, and may not necessarily include everyone who is affected. As Boedeltje and Cornips [32] argue, in complex issues, it is challenging to include all affected people in effective deliberation and decision-making. Given that people are not equally able to make themselves heard, due to their unequal competence, power, and resources [33], the ideal of equal opportunities for all affected people cannot be achieved in the smart city concept, but rather it can only be approached [21].

In this context, it is important to consider that politicians' values and corresponding approaches and practices will impact upon citizens' perceptions of democracy, inclination toward participation, and willingness to comply with policy directives. Those values that result from intermingling the values of politicians and society can therefore naturally be expected to be more realistic than the values of society normatively and passively perceived or identified by politicians [28]. In order to facilitate such processes, Innes and Booher [34] believe that the importance of power differences should be minimized, and rational argumentation should be supported, rather than interest-based advocacy. In addition, as the main focus of the smart city is on competencies and the "ability to identify and solve urban problems" rather than power distribution and the "right to influence", the risk of urban development becoming de-politicization is high [21] (p. 12). This can lead to the selective inclusion of citizens based on their assets and competences rather than representativeness, which is necessary for influencing the development of a city. Therefore, before any participation process, it is important to first understand whose problems are being solved and whose interests are being served [21,35].

Believing that citizens are willing to trade fair processes for effective problem solving or output, legitimacy can be viewed as more utopian than realistic in this context [36]. Moreover, given the early state of research into smart cities, there is no evidence to suggest that they can provide effective problem solving or output legitimacy. This paper investigates how these approaches are perceived and practiced in smart city projects. 


\subsection{Practices}

In order to evaluate the practices, many researchers have drawn on the work of Arnstein [37], who describes eight levels on the "ladder of citizen participation", ranging from "no participation" to "full citizen power" [9]. Cardullo and Kitchin [9] use Arnstein's ladder in the smart city context and agree that it has utility to examine how citizens are positioned in practice. However, they argue that it does not fully account for the type, role, function, political discourse/framing, and modality of citizen participation. In order to fit in the smart city topic, they broadened Arnstein's model, as Table 1 shows, calling it a scaffold of smart citizen participation.

Table 1. Scaffold of smart citizen participation [9].

\begin{tabular}{|c|c|c|c|c|c|}
\hline Form and Level c & Participation & Role & $\begin{array}{c}\text { Citizen } \\
\text { Involvement }\end{array}$ & $\begin{array}{c}\text { Political } \\
\text { Discourse/Framing }\end{array}$ & Modality \\
\hline \multirow{3}{*}{ Citizen power } & Citizen control & $\begin{array}{l}\text { Leader, } \\
\text { member }\end{array}$ & $\begin{array}{l}\text { Ideas, vision, } \\
\text { leadership, }\end{array}$ & $\begin{array}{c}\text { Rights, } \\
\text { social/political }\end{array}$ & \multirow{3}{*}{$\begin{array}{l}\text { Inclusive, } \\
\text { bottom-up, } \\
\text { collective, } \\
\text { autonomy, } \\
\text { experimental }\end{array}$} \\
\hline & $\begin{array}{l}\text { Delegated } \\
\text { power }\end{array}$ & $\begin{array}{c}\text { Decision-maker, } \\
\text { maker }\end{array}$ & $\begin{array}{c}\text { ownership, } \\
\text { create }\end{array}$ & $\begin{array}{l}\text { citizenship, } \\
\text { commons }\end{array}$ & \\
\hline & Partnership & Co-creator & $\begin{array}{l}\text { Negotiate, } \\
\text { produce }\end{array}$ & \multirow{2}{*}{$\begin{array}{l}\text { Participation, } \\
\text { co-creation }\end{array}$} & \\
\hline \multirow{3}{*}{ Tokenism } & Placation (I2) & Proposer & Suggest & & \multirow{6}{*}{$\begin{array}{l}\text { Top-down, civic } \\
\text { paternalism, } \\
\text { stewardship, } \\
\text { bound-to-succeed }\end{array}$} \\
\hline & Consultation & $\begin{array}{l}\text { Participant, } \\
\text { tester, player }\end{array}$ & Feedback & \multirow[t]{2}{*}{ Civic engagement } & \\
\hline & Information & Recipient & Browse, & & \\
\hline Consumerism & Choice & $\begin{array}{l}\text { Resident, } \\
\text { consumer }\end{array}$ & consume, act & $\begin{array}{l}\text { Capitalism, } \\
\text { Market }\end{array}$ & \\
\hline \multirow[t]{2}{*}{ Non-participation } & Therapy & \multirow{2}{*}{$\begin{array}{l}\text { Patient, learner, } \\
\text { user, product, } \\
\text { data-point }\end{array}$} & \multirow{2}{*}{$\begin{array}{l}\text { Steered, } \\
\text { nudged, } \\
\text { controlled }\end{array}$} & \multirow{2}{*}{$\begin{array}{l}\text { Stewardship. } \\
\text { Technocracy, } \\
\text { paternalism }\end{array}$} & \\
\hline & Manipulation & & & & \\
\hline
\end{tabular}

Starting from the bottom of the scaffold, the last row or rung of this model refers to non-participation (manipulation and therapy), in which people will be steered and educated in a top-down governing mode. The next stage, which is additional to the original model of Arnstein, is consumerism. In such a framing, people can embrace a "smart lifestyle", but their choice is largely predetermined by service providers [9]. In general, services are designed and operated with limited involvement by citizens, other than as users, who may have a chance to provide feedback in the design phase or act as beta-testers of products in the production phase.

The next stage is tokenism, including information, consultation, and placation, in which people have a voice and some degree of autonomy, even though they do not have power to directly change or influence the decisions and plans. Cardullo and Kitchin [9] believe that the use of smart technology for information and consultation may strengthen the barrier for engagement due to the requirement for digital competencies, which are influenced by social characteristics such as age, gender, and education. Here, the legitimacy of planning is measured by the effectiveness and efficiency of the chosen solutions, and participation is only seen as valuable to the extent that it contributes to instrumental goal attainment [25]. Since the focus is on including resource-controlling actors or right-holders, in order to ensure and increase the system capacity, only citizens with specific knowledge, capital, and status make up the main target group.

The final and highest level of participation is citizen power, including partnership, delegated power, and citizen control, in which citizens have more formal power to take an active role and contribute to change and decision-making. Arnstein's framework is rooted in the concept of power and the extent to which it can induce "significant social reform", affecting the outcome of a process and eventually redistributing "the benefits of affluent society" rather than being only an "empty ritual" [37] (p. 216). In other words, participation and power can work together by reflecting an ideal of society 
that is more equal and fairer with respect to plan- and decision-making [9]. In this respect, Refstie and Brun [38] argue that, in order to enable citizens' voices to be heard and affect decision-making, it is not enough to invite them into planning and decision-making processes, but they should have an opportunity to claim and invent the participation space themselves. Therefore, direct participation should be the combination of invited, claimed, and invented participation spaces. However, the last stage of citizen power is barely realized in smart city projects [9], which are externally funded. Citizens are not involved in proposal-writing and goal-setting. Although their engagement during the project itself is usually labeled as citizen-centric, their influence is limited to project outcomes within the predetermined scope of the project. Therefore, citizens' influence in the later stages is naturally limited, since reversing the project's course is almost impossible.

In this paper, we argue that positioning practices based on Arnstein's "ladder" or Cardullo and Kitchin's "scaffold" requires an improved understanding of the main actors' approaches and practices, which are influenced by different structural and functional elements. None of the above-named authors has investigated which elements can influence a shift from one level to another level of citizen participation ladder/scaffold. This paper tries to fill this gap.

\subsection{Influences on Prevailing Approaches and Practices}

The main actors and authorities can perceive participatory and deliberative democracy as complementary [39]. The former then depends on deliberative processes, in which representative politics will express citizens' input while constructively supporting their sense of identity and community. The latter also depends on resonating with citizens' values and identity through participatory processes to work effectively [23]. On the other hand, the main actors could trade between participatory and deliberative democracy based on expediency for predetermined goals. The more participatory processes can be seen as a threat to efficiency while a greater output by non-majoritarian institutions can be seen as a shortage of citizens' political input [40]. Therefore, depending on the institutional setup and culture, different institutions, traditions, and practices will approach the concept of participation in different ways. Indeed, policy-making is a complex, interactive process, without a beginning or end [41]. Analysis of any decision-making setting must consider how the system is structured and organized, but also the way in which the structures in the system work (referring to the process of bargaining and compromise-seeking) in a nonlinear way.

Analyzing both the structures and functions of planning processes enables us to take a more systemic view of participation practices, while still accounting for the numerous dynamic interactions of multiple approaches across scales and policy spheres [42,43]. Furthermore, as Forester [44] argues, it is important to recognize the cumulative influences of the broad political, social, economic, and cultural contexts of the system and the way in which institutions/individuals interact, based on their positions, roles, power, and networks.

Structures are organized or institutionalized in a specific manner and consist of many interrelated and interdependent-but also autonomous-individuals existing at different levels of society: national, regional, and local [42]. Structures help to understand where the network stands and what the reality of actors' relations and networks are, in terms of their different knowledge use, connectivity, and capacity [43]. The way actors are connected and interact in a system based on their interdependency and the asymmetry of their knowledge, connectivity, and capacity represents the system's overall functionality. As it was mentioned earlier, different actors (e.g., citizens) may have access to adequate resources to take an action. However, they may fail to do so, as they are unable to act due to legal or political constraints, lack adequate motivation (incentives or disincentives), or are opposed to the action, strategically or philosophically. Therefore, as Dente [45] argues, actors' practices may be different from their approaches. In this regard, this paper tries to understand which approaches and practices of democracy (consistent or inconsistent) are used by different actors and which structures and processes may inhibit or reinforce them. Figure 1 gives an overview of the way this paper combines various theoretical concepts, to create a conceptual framework for studying citizen participation. Actors' 
approaches and practices are evaluated based on participatory versus deliberative democracy, input versus output legitimacy, and/or "by" and "of" people versus "for" people mechanisms. As Figure 1 shows, actors' practices can be positioned in the scaffold of smart city participation, from citizen power to non-participation. There may be a mismatch or similarity between their practices and approaches which is influenced by different structural and functional elements.

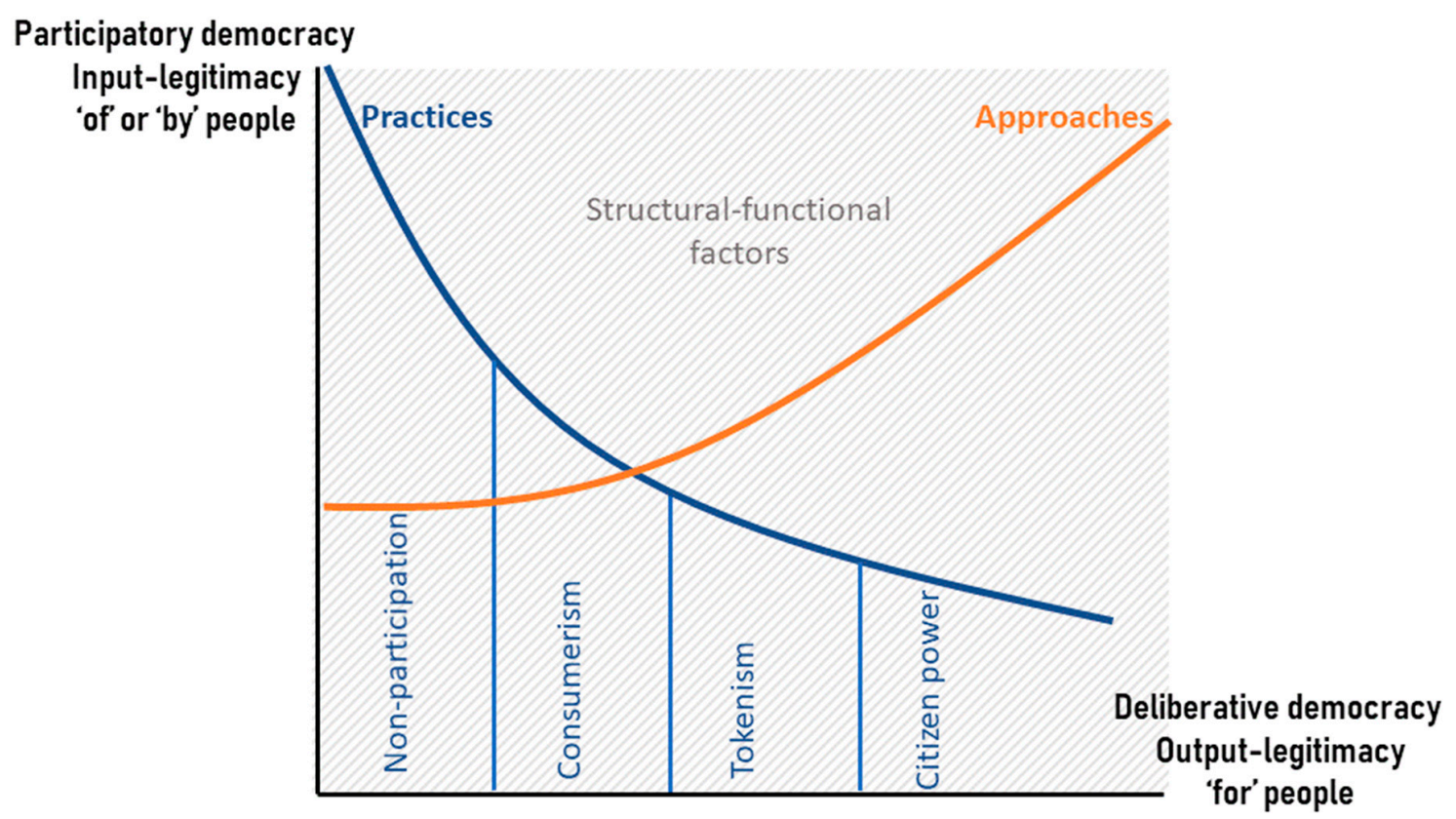

Figure 1. Conceptual framework for evaluating approaches and practices toward citizen participation.

\subsection{Citizen Participation in Norway}

Through the 1990s, the principles of public participation became fully accepted in Norway. Today, the Norwegian Planning and Building Act mandates that citizens and other stakeholders have the right to give statements or voice opposition to the plan. Municipalities are the lowest level of government in Norway and have the authority for urban planning and development. Therefore, municipalities have the legal requirement to provide public hearings and ensure the publicity of their planning proposals through public debates, exhibitions, workshops, and petitions [46]. The planning department in municipalities is responsible for organizing or supervising the planning process, including the participation of different stakeholders. The administrative bodies of municipalities prepare plans and the elected bodies decide upon them; a political planning committee processes the plans, and the municipal council makes the final decision.

The politically driven neoliberal trend in Norway has also given private entrepreneurs a prominent and driving role in urban development, especially regarding decisions about building "what and where" $[25,36]$. Even though the intention of neoliberalism was to increase efficiency and effectiveness through public-private partnerships, Fiskaa [46] believes that neoliberalism has strengthened the position of landowners, business interests, and developers, in many cases at the expense of public participation. This can create a dependency on markets for the implementation of policy goals.

\section{Methodology}

\subsection{Research Approach}

This research adopts a constructivist approach and qualitative case-study method. The qualitative approach is appropriate for researching the problem of citizen participation, which requires learning and interpreting individuals' views and assessing a process of decision-making that is influenced by different social and political settings that change over time [47]. 
The justification of our methods is to understand the following:

- The characteristics of citizen participation in Trondheim's policy-making processes,

- The meanings that the participants themselves attribute to these interactions,

- What is/was happening in relation to citizen participation at the moment,

- What structures and processes have inhibited or reinforced the prevailing approaches and practices, including the complexity of social and political interactions [48].

We applied a descriptive case-study approach, to illustrate the prevailing approaches and practices toward citizen participation within its real and complex context. Case-study research allows prior theories as a sensitizing and guiding device for data collection [49]. In addition, we used the pilot project approach, which is initiated for dealing with practical problems, where no instruments, experiences, or know-how preexist, and thus it helps to produce ready-made solutions [50].

\section{+ CityxChange Pilot Project in Trondheim}

The case followed is the +CityxChange pilot project in Trondheim, which is funded by the EU Horizon 2020 (H2020) research and innovation program in the topic "Smart Cities and Communities", from November 2018 to November 2023. This particular H2020 call funded projects that would enhance "citizen ownership of the solutions through effective and systematic involvement in participatory ... (and) ... consultation processes for co-design, co-development and co-implementation of visionary urban planning" [51] (p. 116).

The funding for +CityxChange is 300 million Norwegian Kroner. The consortium for +CityxChange comprises 32 partners, consisting of the municipalities of the seven cities involved, two universities, nine large enterprises, two distributed network operators, nine SMEs, and three non-profit organizations (see [52] for the list of partners). The Norwegian University of Science and Technology (NTNU) is coordinating the project with the two Lighthouse Cities of Trondheim and Limerick and five Follower Cities of Alba Iulia, Písek, Sestao, Smolyan, and Võru.

Trondheim, a case of this paper, is the third largest city in Norway, with a population of about 190,500 people. It is known as the technological capital of Norway, hosting the Norwegian University of Science and Technology (NTNU) and the research foundation SINTEF. One of the main goals of Trondheim is to develop the city into a smart and sustainable city, where it is easy for the inhabitants to live environmentally friendly [52]. Trondheim municipality is governed by the city council and the mayor and is run under the Planning and Building Act, the Pollution Act, and other relevant thematic laws and regulations.

There are eleven demonstration projects which are developed in the Lighthouse Cities and will be replicated in the Follower Cities. These demonstration projects will showcase how digital technologies can be exploited to improve the quality of life, make cities more climate-friendly and productive, and facilitate business development, as well as citizen participation.

The aim of +CityxChange is to improve the quality of life through the use of digital services, co-producing more energy than is consumed, and exchanging experiences with other cities across Europe [53]. Co-creation of positive energy blocks and districts (PEB/PED) will be fulfilled through citizen participation, integrated planning, common energy markets, regulatory sandboxes, and business models. The expected outcome is to create recommendations for new policy intervention, market (de)regulation and business models that deliver positive energy communities, integrating e-Mobility as a Service (eMaaS). Besides building up knowledge and competence within the municipality administration, the participation in the project is also seen as a fertilizer to step up urban sustainable transition. The project strives for bottom-up innovation, in which the interaction between different stakeholders and citizens develops novel knowledge that can positively affect policy-making, in which policymakers can be the bridge to practice. According to +CityxChange [4], the citizen-centered has the following objectives: 
- Enabling citizen participation and ownership for solutions for the transformation toward a positive energy city;

- Developing a Bold City Vision 2050 and guidelines that create and trigger an integrated approach to sustainable urban development, citizen/private company/NGO integrated processes, and a way ahead that ensures inclusion;

- Co-creating distributed positive-energy blocks through citizen participation, creating a citizen-participation playbook and platform.

Within the project, there is a whole working package specifically focusing on creating a framework for participatory design and co-creation that will enable citizens to develop the sense of ownership that is critical for managing the change toward living in a positive-energy city.

Part of the ideological underpinnings of the mission, delivery, and replication of +CityxChange is to explicitly consider citizen roles rather than simply treat them as consumers or recipients of smart city initiatives. In this regard, this paper is interested in attending to the journey of policy from the transnational and relational context of the European funding strategy to the interpretation and eventual adaptation in the pilot project Trondheim. The consideration of such an ongoing process gives extra scope to this research, since it imposes new lessons and guidelines for the upcoming actions. In addition, since the +CityxChange project is in its early stages, the researchers have a chance to positively influence the process and its outcome, remedying potential or existing deficiencies. Accordingly, the overall goal is to open up new discussions and relevant questions for both researchers and policymakers, building on well-known pitfalls that may be common to global smart cities and discourses.

\subsection{Research Methods}

The research questions are as follows:

1. What are the prevailing approaches, understandings and practices in relation to citizen participation amongst the key actors involved +CityxChange?

2. Which structures and processes have influenced the prevailing approaches and practices?

In order to approach these questions, participatory action research and semi-structured interviews are applied, in order to investigate different main actors' perspectives, interests, and strategies, reflecting on and learning from a citizen-centric project. Participatory action research perspective can set a benchmark between the project's starting point and our findings. Therefore, research diaries and ethnographic accounts have been used as discussion material, as well as a basis for the interviews.

From the participatory-action research perspective [54,55], one of the authors was involved in preparing the +CityxChange project proposal and has continuously participated in the project meetings and workshops. One of the other authors has an official position within the project, working with Work Package 9-Inter-Project Collaboration and Clustering. Since NTNU has been a part of the quadruple helix in the pilot, NTNU researchers are part of the transformative research relationship in Trondheim. The municipality has invited the authors to participate and have debates on citizen participation. Some of the authors' parallel projects in smart cities and open innovation, in partnership with the municipality, have given them an extra chance to have frequent informal conversations and better acquaint with the main actors' real approaches and practices in relation to the existing structural and functional barriers.

Ten semi-structured interviews were conducted with different actors of +CityxChange, including three people from the municipality, two people from NTNU, two people from the private sector, and three citizens influenced by + CityxChange (see Table 2). With semi-structured interviews, the researchers had a clear list of issues focusing on approaches and practices to be addressed and questions to be answered, based on the informants' role in the project. However, the questions were gradually revised and redeveloped, based on the informants' sequential responses. Moreover, by using a semi-structured interview with a fairly open framework, the researchers aimed for focused, conversational, and two-way communications, but with an emphasis on the interviewees elaborating 
on points of interest. The purpose was to give informants the freedom to express their views in their own terms and develop their ideas, thereby contributing more reliable and comparable qualitative data to the research [56]. Table 2 shows the list of interviewees, including their institution and background.

Table 2. List of interviewees.

\begin{tabular}{lll}
\hline \multicolumn{1}{c}{ Number } & Institution & Background \\
\hline Interviewee 1 (I1) & Trondheim Municipality/Environmental Unit & Energy and Climate \\
\hline Interviewee 2 (I2) & Trondheim Municipality/CEO & Leadership \\
\hline Interviewee 3 (I3) & Trondheim Municipality/Urban Planning Unit & Architecture \\
\hline Interviewee 4 (I4) & NTNU/Project Administration & Information Technology (IT) \\
\hline Interviewee 5 (I5) & NTNU/Project Administration & Urban Planning \\
\hline Interviewee 6 (I6) & Electricity company (private sector) & Energy \\
\hline Interviewee 7 (I7) & Real Estate company (private sector) & Economy \\
\hline Interviewee 8 (I8) & Citizen, lives in one of the demonstration areas & Female, Middle age \\
\hline Interviewee 9 (I9) & Citizen, lives in one of the demonstration areas & Male, Middle age \\
\hline Interviewee 10 (I10) & Citizen, lives in one of the demonstration areas & Male, Young adult \\
\hline
\end{tabular}

Regarding the interview sampling, on the one hand, we were looking for specific informants, either with a formal power to influence the process and outcome, or with important information and insight that their positions would give. Thus, our sampling method was "nonprobability purposive expert sampling" in which we purposefully or intentionally selected individuals instead of conducting random sampling [57]. On the other hand, we were seeking inputs from the citizens, to explore how they perceive and evaluate participatory practices. Therefore, we needed to randomly select some citizens who live in the demonstration area. In order to support our arguments, we use some of the quotations from our interviewees. Quotations are marked by the abbreviation (In) and I1-I7 are referred to the key local actors of +CityxChange who have the authority and responsibility for citizen participation. Since the interviewees wanted their anonymity protected, their quotations just include their number, which is mentioned in Table 2. In some situations, we had to alter the interviewees' original word due to grammatical errors or to add some word(s) to better explain the quotation, regarding the context of the interview. In these situations, we used brackets to show our own wordings.

Interviews were recorded, transcribed, and coded manually, according to key themes of the conceptual framework, and transferred into the Excel file.

As it is already mentioned in Section 2, people's different perceptions and interpretations of an issue can challenge a coordinated action. Therefore, in order to better understand how citizen participation was framed within the +CityxChange project, the starting point was to understand how main actors interpret the project's goals and mission, and then how they make sense of citizens and their role within the project.

Some of the main questions that were asked from the main actors were as follows:

- How do you define the smart city?

- What are the main objectives of +CityxChange?

- What does citizen participation mean in your opinion? What can we do to improve it?

Some of the main questions that were asked from the citizens were as follows:

- Have you heard about the smart city? Do you know that Trondheim wants to become smart?

- How do you evaluate the citizen participation in Trondheim?

- What is or should be the role of citizens?

- How can citizens better participate in the urban development process? Are the prevailing practices of authorities satisfactory? 
Some codes were based on the researchers' own naming convention, such as smart city, +CityxChange, citizens' engagement and participation, municipality's strategic planning, decision-making, decision-power, role, interest, and culture. The chosen technique of analysis for this study was pattern matching, in which the findings are compared with our theoretical framework (see Table 1). Therefore, we recoded based on the standardized labels taken from the theoretical framework, such as "democracy", "information", "manipulation", "participation ladder", "input legitimacy", and "output legitimacy". These codes were juxtaposed and put into different arrays of citizen participation, from citizen power to non-participation (see Figure 1), and matrices of two categories: approaches and practices. Then, based on the relation between these variables and the frequency of different words, a relational flowchart or matrix was drawn by the researchers. The results are partly shown in the first table and the last figure in Section 4. Findings and Discussion. (see Table 3 and Figure 4). The researcher team then met to discuss and analyze the data as a group, discussing the link between the different researchers' own observations during their participation in the pilot project's meetings and workshops. This analysis was formative for the arguments in the discussion.

Table 3. Main actors of +CityxChange approaches toward citizen participation.

\begin{tabular}{|c|c|c|c|c|}
\hline \multicolumn{5}{|c|}{ Trondheim Municipality } \\
\hline I1 quotation: & \multicolumn{4}{|c|}{$\begin{array}{c}\text { "Reducing the gap between citizens and the decision-maker authorities. } \\
\text { Developing an overarching framework for citizen participation, based on } \\
\text { experiences gained within +CityxChange". }\end{array}$} \\
\hline \multirow{3}{*}{$\begin{array}{l}\text { Interpretation of } \\
\text { key theme }\end{array}$} & \multicolumn{2}{|c|}{ Participatory democracy } & \multirow{2}{*}{$\begin{array}{l}\text { Deliberative } \\
\text { democracy } \\
\text { (for people) }\end{array}$} & \multirow{2}{*}{$\begin{array}{l}\text { Codes that represent } \\
\text { scaffolds of smart city } \\
\text { participation (Table } 1)\end{array}$} \\
\hline & By people (voice) & $\begin{array}{l}\text { Of people } \\
\text { (vote) }\end{array}$ & & \\
\hline & $\begin{array}{l}\text { Delegate power } \\
\text { and employ their } \\
\text { experiences }\end{array}$ & & $\begin{array}{l}\text { Develop a } \\
\text { citizen-centric } \\
\text { framework }\end{array}$ & $\begin{array}{l}\text { Delegated power and } \\
\text { partnership. Citizens } \\
\text { are decision-makers, } \\
\text { ownership, commons, } \\
\text { collective }\end{array}$ \\
\hline I2 quotation: & $\begin{array}{l}\text { "+CityxChange w } \\
\text { related to citizen } \\
\text { outcomes. To satisfy }\end{array}$ & $\begin{array}{l}\text { find out wha } \\
\text { eeds, citizen } \\
\text { e end-user d }\end{array}$ & $\begin{array}{l}\text { bens' interest an } \\
\text { be the jury and } \\
\text { d and develop g }\end{array}$ & $\begin{array}{l}\text { eds are. If the decision } \\
\text { e power to decide the } \\
\text { physical environments". }\end{array}$ \\
\hline \multirow[b]{3}{*}{$\begin{array}{l}\text { Interpretation of } \\
\text { key theme }\end{array}$} & \multicolumn{2}{|c|}{ Participatory democracy } & \multirow{2}{*}{$\begin{array}{l}\text { Deliberative } \\
\text { democracy } \\
\text { (for people) }\end{array}$} & \multirow{2}{*}{$\begin{array}{l}\text { Codes that represent } \\
\text { scaffolds of smart city } \\
\text { participation (Table 1) }\end{array}$} \\
\hline & By people (voice) & $\begin{array}{l}\text { Of people } \\
\text { (vote) }\end{array}$ & & \\
\hline & $\begin{array}{l}\text { Empower citizens } \\
\text { and employ their } \\
\text { interests }\end{array}$ & & $\begin{array}{l}\text { Develop a } \\
\text { good city }\end{array}$ & $\begin{array}{l}\text { Delegated power and } \\
\text { placation. Citizens are } \\
\text { proposer and } \\
\text { decision-maker but also } \\
\text { recipient and consumer. } \\
\text { Rights. Hybrid } \\
\text { modality (bottom-up } \\
\text { and top-down) }\end{array}$ \\
\hline
\end{tabular}


Table 3. Cont.

\section{Trondheim Municipality} I3 quotation: and co-creators of the outcomes related to their needs. To provide real opportunities for citizens to effectively influence the planning processes".

\begin{tabular}{|c|c|c|c|c|}
\hline \multirow{3}{*}{$\begin{array}{l}\text { Interpretation of } \\
\text { key theme }\end{array}$} & \multicolumn{2}{|c|}{ Participatory democracy } & \multirow{2}{*}{$\begin{array}{l}\text { Deliberative } \\
\text { democracy } \\
\text { (for people) }\end{array}$} & \multirow{2}{*}{$\begin{array}{l}\text { Codes that represent } \\
\text { scaffolds of smart city } \\
\text { participation (Table 1) }\end{array}$} \\
\hline & By people (voice) & $\begin{array}{l}\text { Of people } \\
\text { (vote) }\end{array}$ & & \\
\hline & Empower citizens & & $\begin{array}{l}\text { Provide real } \\
\text { participation } \\
\text { opportunities }\end{array}$ & $\begin{array}{l}\text { Partnership, placation } \\
\text { and consultation. } \\
\text { Citizens are co-creators } \\
\text { and proposers, }\end{array}$ \\
\hline
\end{tabular}

\section{NTNU}

"Engage stakeholders and citizens into the project to provide them a platform, in 14 quotation: which they can help each other to upgrading their old buildings since they do not have enough money to build new positive energy building alone".

\begin{tabular}{|c|c|c|c|c|}
\hline \multirow[b]{3}{*}{$\begin{array}{l}\text { Interpretation of } \\
\text { key theme }\end{array}$} & \multicolumn{2}{|c|}{ Participatory democracy } & \multirow{2}{*}{$\begin{array}{l}\text { Deliberative } \\
\text { democracy } \\
\text { (for people) }\end{array}$} & \multirow{2}{*}{$\begin{array}{l}\text { Codes that represent } \\
\text { scaffolds of smart city } \\
\text { participation (Table 1) }\end{array}$} \\
\hline & By people (voice) & $\begin{array}{l}\text { Of people } \\
\text { (vote) }\end{array}$ & & \\
\hline & $\begin{array}{l}\text { Inform and educate } \\
\text { people. Get } \\
\text { feedback }\end{array}$ & & $\begin{array}{l}\text { Co-creation. } \\
\text { Create PED }\end{array}$ & $\begin{array}{l}\text { Consultation and } \\
\text { information. } \\
\text { They are recipient, } \\
\text { tester, and proposer. } \\
\text { Civic paternalism, } \\
\text { stewardship, } \\
\text { bound-to-succeed }\end{array}$ \\
\hline I5 quotation: & \multicolumn{4}{|c|}{$\begin{array}{l}\text { "Engaging people to be informed about the +CityxChange project and to co-create } \\
\text { things with them so they could come up with better and interesting additional } \\
\text { solutions. Engaging citizens in developing solution for creating PEDs and make the } \\
\text { solutions visible for them". }\end{array}$} \\
\hline \multirow[b]{3}{*}{$\begin{array}{l}\text { Interpretation of } \\
\text { key theme }\end{array}$} & \multicolumn{2}{|c|}{ Participatory democracy } & Deliberative & Codes that represent \\
\hline & By people (voice) & $\begin{array}{l}\text { Of people } \\
\text { (vote) }\end{array}$ & $\begin{array}{l}\text { democracy } \\
\text { (for people) }\end{array}$ & $\begin{array}{l}\text { scaffolds of smart city } \\
\text { participation (Table } 1 \text { ) }\end{array}$ \\
\hline & $\begin{array}{l}\text { Inform people and } \\
\text { employ their } \\
\text { insight and } \\
\text { feedback }\end{array}$ & & $\begin{array}{l}\text { Create PED. } \\
\text { Transparency } \\
\text { and clarity }\end{array}$ & $\begin{array}{l}\text { Consultation and } \\
\text { information. } \\
\text { They are recipient, } \\
\text { tester and proposer. } \\
\text { Civic paternalism, } \\
\text { stewardship, } \\
\text { bound-to-succeed }\end{array}$ \\
\hline
\end{tabular}


Table 3. Cont.

\begin{tabular}{|c|c|c|c|c|}
\hline \multicolumn{5}{|c|}{ Trondheim Municipality } \\
\hline \multicolumn{5}{|c|}{ Private Sector } \\
\hline I6 quotation: & \multicolumn{4}{|c|}{ "To provide good mobility solutions with regard to user demand". } \\
\hline \multirow[b]{3}{*}{$\begin{array}{l}\text { Interpretation of } \\
\text { key theme }\end{array}$} & \multicolumn{2}{|c|}{ Participatory democracy } & \multirow{2}{*}{$\begin{array}{l}\text { Deliberative } \\
\text { democracy } \\
\text { (for people) }\end{array}$} & \multirow{2}{*}{$\begin{array}{l}\text { Codes that represent } \\
\text { scaffolds of smart city } \\
\text { participation (Table 1) }\end{array}$} \\
\hline & By people (voice) & $\begin{array}{l}\text { Of people } \\
\text { (vote) }\end{array}$ & & \\
\hline & $\begin{array}{l}\text { Employ people's } \\
\text { interests and } \\
\text { demands }\end{array}$ & & $\begin{array}{l}\text { Provide good } \\
\text { solution }\end{array}$ & $\begin{array}{l}\text { Consultation and } \\
\text { information/ } \\
\text { non-participation. } \\
\text { They are recipient, } \\
\text { tester and proposer. } \\
\text { Paternalism, } \\
\text { stewardship, } \\
\text { bound-to-succeed }\end{array}$ \\
\hline I7 quotation: & \multicolumn{4}{|c|}{$\begin{array}{l}\text { "To change end-user's behavior to reduce peak load on the grid; knowledge about } \\
\text { end-user's electricity behavior, adaptation of pricing system". }\end{array}$} \\
\hline \multirow[b]{3}{*}{$\begin{array}{l}\text { Interpretation of } \\
\text { key theme }\end{array}$} & \multicolumn{2}{|c|}{ Participatory democracy } & \multirow{2}{*}{$\begin{array}{l}\text { Deliberative } \\
\text { democracy } \\
\text { (for people) }\end{array}$} & \multirow{2}{*}{$\begin{array}{l}\text { Codes that represent } \\
\text { scaffolds of smart city } \\
\text { participation (Table 1) }\end{array}$} \\
\hline & By people (voice) & $\begin{array}{l}\text { Of people } \\
\text { (vote) }\end{array}$ & & \\
\hline & Educate people & & $\begin{array}{l}\text { Reduce energy and } \\
\text { provide good } \\
\text { solution }\end{array}$ & $\begin{array}{l}\text { Non-participation and } \\
\text { consumerism. Citizens } \\
\text { are consumers and } \\
\text { users. Paternalism, } \\
\text { stewardship, } \\
\text { bound-to-succeed }\end{array}$ \\
\hline \multicolumn{5}{|c|}{ Citizens } \\
\hline I8 quotation: & \multicolumn{4}{|c|}{$\begin{array}{c}\text { "Citizens are the end user of the city. Municipality needs to facilitate their needs. } \\
\text { Citizens are Municipality's partner who has an important role to give input or } \\
\text { suggestions from their knowledge to the Municipality. It is better to include the } \\
\text { citizens in the early stage of the planning. Because every citizen has different } \\
\text { knowledge of their living area". }\end{array}$} \\
\hline \multirow{3}{*}{$\begin{array}{l}\text { Interpretation of } \\
\text { key theme }\end{array}$} & \multicolumn{2}{|c|}{ Participatory democracy } & \multirow{2}{*}{$\begin{array}{l}\text { Deliberative } \\
\text { democracy } \\
\text { (for people) }\end{array}$} & \multirow{2}{*}{$\begin{array}{l}\text { Codes that represent } \\
\text { scaffolds of smart city } \\
\text { participation (Table 1) }\end{array}$} \\
\hline & By people (voice) & $\begin{array}{l}\text { Of people } \\
\text { (vote) }\end{array}$ & & \\
\hline & $\begin{array}{l}\text { Include citizens in } \\
\text { decision-making }\end{array}$ & & Better result & $\begin{array}{l}\text { Delegate power and } \\
\text { partnership. } \\
\text { Ideas/vision/inclusive } \\
\text { modality }\end{array}$ \\
\hline I9 quotations: & $\begin{array}{l}\text { "It's better that the } \\
\text { inform citizens ab } \\
\text { board (like } \mathrm{r}\end{array}$ & $\begin{array}{l}\text { nicipality pa } \\
\text { the projects } \\
\text { ence group) }\end{array}$ & $\begin{array}{l}\text { ers with citizens. M } \\
\text { ore making any deci } \\
\text { one of the good way }\end{array}$ & $\begin{array}{l}\text { icipality should actively } \\
\text { n". "Citizens advisory } \\
\text { o reach citizens". }\end{array}$ \\
\hline \multirow{3}{*}{$\begin{array}{l}\text { Interpretation of } \\
\text { key theme }\end{array}$} & \multicolumn{2}{|c|}{ Participatory democracy } & Deliberative & Codes that represent \\
\hline & By people (voice) & $\begin{array}{l}\text { Of people } \\
\text { (vote) }\end{array}$ & $\begin{array}{l}\text { democracy } \\
\text { (for people) }\end{array}$ & $\begin{array}{l}\text { scaffolds of smart city } \\
\text { participation (Table 1) }\end{array}$ \\
\hline & $\begin{array}{l}\text { Involve, consult, } \\
\text { inform, and } \\
\text { empower citizens }\end{array}$ & $\begin{array}{l}\text { Citizens } \\
\text { advisory } \\
\text { board }\end{array}$ & $\begin{array}{c}\text { Better } \\
\text { decision-making }\end{array}$ & $\begin{array}{c}\text { Partnership and } \\
\text { placation. Ownership. } \\
\text { Inclusive modality }\end{array}$ \\
\hline
\end{tabular}


Table 3. Cont.

\begin{tabular}{|c|c|c|c|c|}
\hline \multicolumn{5}{|c|}{ Trondheim Municipality } \\
\hline I10 quotation: & \multicolumn{4}{|c|}{$\begin{array}{l}\text { "We don't have role as decision maker, it is still municipality and the political party } \\
\text { who have rights to make decisions. However, politicians are quite weak when it comes } \\
\text { to developers' interest". }\end{array}$} \\
\hline \multirow{3}{*}{$\begin{array}{l}\text { Interpretation of } \\
\text { key theme }\end{array}$} & \multicolumn{2}{|c|}{ Participatory democracy } & \multirow{2}{*}{$\begin{array}{l}\text { Deliberative } \\
\text { democracy } \\
\text { (for people) }\end{array}$} & \multirow{2}{*}{$\begin{array}{l}\text { Codes that represent } \\
\text { scaffolds of smart city } \\
\text { participation (Table 1) }\end{array}$} \\
\hline & By people (voice) & $\begin{array}{l}\text { Of people } \\
\text { (vote) }\end{array}$ & & \\
\hline & Delegate power & $\begin{array}{l}\text { Empower } \\
\text { politicians }\end{array}$ & & $\begin{array}{l}\text { Delegate power. } \\
\text { Autonomy and } \\
\text { collective modality }\end{array}$ \\
\hline
\end{tabular}

\subsection{Limitations of the Study}

The main limitation of this study refers to the nature of qualitative research as labor-intensive and time-demanding processes. Since this type of research is based more on opinion, personal experience, knowledge, and judgment, rather than results, it is difficult to verify the findings. In addition, all qualitative studies are unique, making it difficult to replicate them [58].

The key local actors in this study are/were very busy people, and it was difficult to get through to all of them. This had reduced the speed at which the interviews were conducted. In addition, different factors, such as job or project context and the broader organizational culture, might influence their responses. In addition, their immediate interest, such as external rewards/punishments or the culture, values, and principles of the society or organization that they belong to might also affect their responses [59]. Even if they might be aware of these influences, they might not be willing to admit it. Therefore, they might unconsciously modify their responses or hesitate to bring up the negative aspects of democracy or citizen participation. Thus, it is important to acknowledge that the researchers were getting the information only as they were willing to pass it on in the interview situations.

Interviewing citizens was challenging, due to their lack of motivation and interest. Building trust and attracting their attention demanded more time and resources. Moreover, we needed to delve into personal interaction for data collection, which often caused our discussion to deviate from the main question.

Interviewees' language style and vocabulary size might be different from the researchers', and this might raise considerable misunderstanding on the part of the interviewers and interviewees. Therefore, instead of looking for whether the informant was telling the truth, the researchers' focus was on what the informants' statements reveal about their feelings and perceptions, and what inferences could be made from them about the actual events they had experienced.

\section{Findings and Discussion}

4.1. Prevailing Approaches, Understandings, and Practices in Relation to Citizen Participation amongst the Key Actors Involved in + CityxChange

When we asked the perspectives of our interviewees, it was revealed that most of the partners at NTNU and Municipality have a complementary approach toward citizen participation, implying that they aim not only at giving actual decision-making power to citizens (by people) but also at effectiveness of the policy outcomes (for the people). Employees from both NTNU and Trondheim Municipality involved in the project see "data/technology as a tool for co-creation, realizing a better interface between citizens and policy-making" (I1). They consensually believe that "digital tools, open data and smart solutions can help to reach democracy by spreading information, and reach broader group of people, with an expectation that people react faster" (I2). In addition, "smart city will use digital technologies to enhance performance and wellbeing of the city, reducing cost and resource 
consumption (for the people: output-oriented), and to engage more effectively and actively with its citizens (by the people: input-oriented)" (I4).

When we asked about the informant's opinion, none of them referred to the representative democracy through "vote" (of people). Indeed, all strongly believed that citizens should have an active role from the early stages of the planning. Such a non-electoral citizen-participation approach, as Joss, et al. [10] describe, is aligned with the pragmatism, collaborative, and Habermasian approaches, in which citizens should have an opportunity to directly explore and understand problems, interact with decision-makers, and contribute to the decision process.

On the other hand, citizens interestingly were very mindful about the role and power of their representatives (politicians as well as community leader), the indirect participation or "of" people mechanism, throughout their interviews. The following are two examples:

"This system (i.e., indirect participation) is actually good if it runs the way it should be! Because politicians are the people's representative. However, we need to see whose interests are heard. It is always the majority that is heard, though the minority voice may be the right one. The point is that people's voice may be considered, but the dangerous thing is that the majority's voice is not always right" (I9).

"People's voice is better considered through the administrative leader of the project that through the politicians since the project leader has more knowledge about the project. Politicians sometimes do not have practical knowledge. However, if we talk about affecting the decision, it is better to go to the politicians since they hold the highest legitimate power in deciding the outcome of the project" (I10).

Furthermore, the private sector's perspective was more output- and efficiency-oriented, aiming at using technology to change behaviors or attitudes of citizens/users for better unitization of services.

In Table 3, we provide a brief overview of our interpretations of the interviewees' approaches, in respect to the conceptual framework developed in Section 2.

Even though the main actors (interviewees 1 to 7 ) mentioned that they aimed for increasing citizens' influence in the decision-making, throughout our conversations and in different settings, it is not easy to position their answers only in one level of Cardullo and Kitchin's model [9]. They often pointed to a multiplicity of citizens' roles at one time. In addition, we realized that there was little discussion on how citizens might be empowered or could actively bring up their own concerns, transfer their ambitions, and exercise their power within and beyond the project. On the other hand, the key actors usually assign the responsibility to authorities to set goals and decide on behalf of citizens, e.g., how they should live (in a sustainable way), as the statement below shows.

"The aim of (the) project is to incentivize citizens to change behavior into a more sustainable manner" (I6).

In addition, they markedly use passive language to refer to citizens (e.g., "to make citizens behave" (I4), or "citizens will have an ability to participate" (I2), or "it should be easy for citizens to live in an environment friendly way"(I1), or "citizens will help to find solutions to reach SDG" (I3)). They have idealistically or hypothetically described how citizens "should" experience the process and decided what is good for them.

They mostly envision citizens as "learners", with the aim of educating them so that they adopt a certain behavior in line with sustainable development. Therefore, the prevailing practices are more instrumental rather than normative or political. In other words, citizens are encouraged to help in providing solutions or to give feedback, or to perform certain roles and responsibilities-but not to be empowered to challenge or replace the fundamental political rationalities or to voluntarily shape an issue or plan. Additionally, citizens have to perform within the bounds of expected and acceptable behavior, and it is not certain whether they can transgress or resist any of the project's social and political norms [9]. For instance, consider the statement below:

"A project tries to make citizens be a part of community grid or community energy exchange to trade and share energy ... Citizens will have an ability to participate in the development of $+C X C^{\prime} s$ solutions and to find a way in making the solutions visible" (I5). 
Citizens have a choice to embrace a "smart lifestyle" by becoming a resident in a smart building or district, enhancing the standard of their living through improved services and technologies. However, this is predetermined by the planners or authorities, and citizens' opportunities to radically reconfigure their choice are diminished. Therefore, the intention of involving citizens cannot be more than asking their feedback or manipulating/fostering their willingness to comply in order to inhibit problems of implementation. In addition, the citizens' right or opportunity to participate in community energy exchange mainly depends on the resources they can contribute to the process. They are steered, controlled, and nudged to act in certain ways, being treated as consumers, testers, or sources of data. This is aligned with the argument of Cardullo and Kitchin [9], who believe that main actors' have instrumental and paternalistic practices and use citizens as beta-testers of solutions, products, or policies. This is also in line with the description of how citizenship changes in smart cities, due to the commercial interest of key actors being more powerful than the public interest [6]. As one of the interviewees mentioned, +CityxChange is an "innovation project, a site of experimentation and target market that focus(es) on having things deployed through speculative strategies of profit-making and testing people's reaction to the idea" (I4).

It is already confessed that accomplishment of the project is seen to be at the expense of use values, social needs, and public goods. Therefore, the final goal is more important than the means, and measures of citizen participation should ensure the EU's energy markets and environmental objectives rather than the democratic legitimacy. Thus, participation is most commonly employed as valuable to the extent that it contributes to the project's overarching goals, implying the output legitimacy.

Even though many participatory workshops were held to give citizens an opportunity to formulate their own topic, they were owned, run, and framed by either Trondheim Municipality or NTNU, who selected and invited specific groups of citizens. According to our interviewees, despite the highly ambitious perspectives on citizen participation, neither NTNU nor Trondheim Municipality know to what extent the citizens can have/gain control and power to impact on the outcome of +CityxChange. Correspondingly, the form and level of participation, intentionally or unintentionally, were (and still is) circumscribed and hamstrung by these actors. In the current situation, it is impossible to expect the level of participation to crossover to "tokenism" and go higher than "informing" or "consultation". The bottom-up approaches attempted by key local actors in the public sector contrasts with the top-down narrative shaped by the EU policy objective.

According to the self-evaluation of the main actors, the prevailing practices are not productive and satisfactory:

"The citizen engagement activities that have been done are not good enough" (I2).

"The current situations are far away from what the citizens can do until decisions are made" (I3).

While citizens could not evaluate +CityxChange as none of the interviewed citizens have heard about the project, still their general feedback would be beneficial to the project. Indeed, the lack of their information/knowledge about +CityxChange itself is something to consider. The statements below represent citizens' general opinions about their roles and power in urban-planning processes.

"We (citizens) do not know our role in the urban planning process. We do not know how we can deliver our opinions, complaints and inputs, for example regarding urban planning development. We are not sure whether we have the right to give our opinion or not" (I8).

"We (citizens) don't have a role as decision maker, it is still (the) municipality and the political party who have rights to make decisions" (I9).

"(Decision-making) is a game between bureaucrats, developers, and politicians. How the citizens affect that game is not easy" (I10).

The findings show a potential misfit between the H2020 framework and the municipality's interest to implement a better citizen framework beyond the pilot project. In the next section, we describe and analyze how European and local institutional structures and their functionality have inhibited their practices to match their approaches. 


\subsection{Which Structures and Processes Influence the Prevailing Approaches and Practices?}

Institutional setup of +CityxChange outside the formal administrative planning structure.

The Norwegian municipal plan includes both a social element (samfunnsdel) and a land-use element (arealdel), which must be carried out legally and in accordance with the Norwegian Planning and Building Act. The former includes strategic priorities for the development of society as a whole, public services, and a spatial development policy, in which smart city is situated. The spatial-development policy includes maps and provisions that are legally binding for detailed plans and building permits. Public participation is protected by law in the planning and building act $\$ 5.1$, by which the planning department in each municipality must make the plans available for public scrutiny, through public hearing procedures, and then report to the municipality manager that the public participation mandate has been fulfilled. Therefore, citizens have an opportunity to study the proposal and suggest amendments or protest against the plan.

On the other hand, municipalities can also make strategic plans for specific spatial parts of the municipality or specific topics which can be developed outside the planning system (Act), but these require political support. In Trondheim, the smart city is not a strategic plan, but it is only a complementary and supportive approach adopted to help Trondheim reach its knowledge-based sustainable-development goal. According to the interviewee's statement below, the application of + CityxChange was rejected two times before the European Commission finally approved it. According to our informants, this implication of placing it outside the bureaucratic administrative structure was not deliberate; indeed, it was a creative opportunity to anchor the project in an overarching and more powerful location in the municipal organization. In order to anchor the project, the political support of the municipal chief executive officer (CEO) was needed at the highest level and was already in place. As Giffinger, Fertner, Kramar, and Meijers [5] (p. 4) also state, a city's institutional capacity presumably increases with "the position within the national or international/global urban system and the ability to lobby its needs and interests and to compete for public funding within the hierarchic institutional system". If the +CityxChange project was developed normally and formally, it would have stood under the City Development Department (see Figure 2), acting as a separate unit that should have followed the planning and building act \$5.1. The first two applications were anchored within the urban-planning department, but the last one was moved up to the CEO level. In this regard, + CityxChange acts more independently from administrative structures and routines but is under the direct control and rule of the municipal chief executive officer.

"The proposal of +CityxChange was sent two times to the EU before it finally became approved. In the two first proposals, +CityxChange stood under environmental unit, having a lower position in the organization than it has today. In the last proposal, they raised the project position to stand under the CEO because it would be easier to mobilize all the required resources (by diminishing unnecessary hierarchies). Therefore, even if today partners of the +CityxChange are sitting together, as one working group under the city development office, they report their actions directly to the CEO" (I1).

Figure 2 shows the position of +CityxChange within the formal municipal structure.

According to the interviewee's statement below, the project was approved after the applicants realized the importance of outsourcing and procurement of smart solutions as EU claims for cities' competitiveness. Therefore, the application was rewritten in a way to finally satisfy the EU's predefined objectives.

"Trondheim Municipality thought the reason that the two previous proposals were rejected was due to the lack of holistic approach. The climate plan, which was the focus in the two first applications, was not enough for the city (to win the competition). Therefore, in the third application, the effort was to see the smart city in a much bigger picture than climate plan" (I1). 

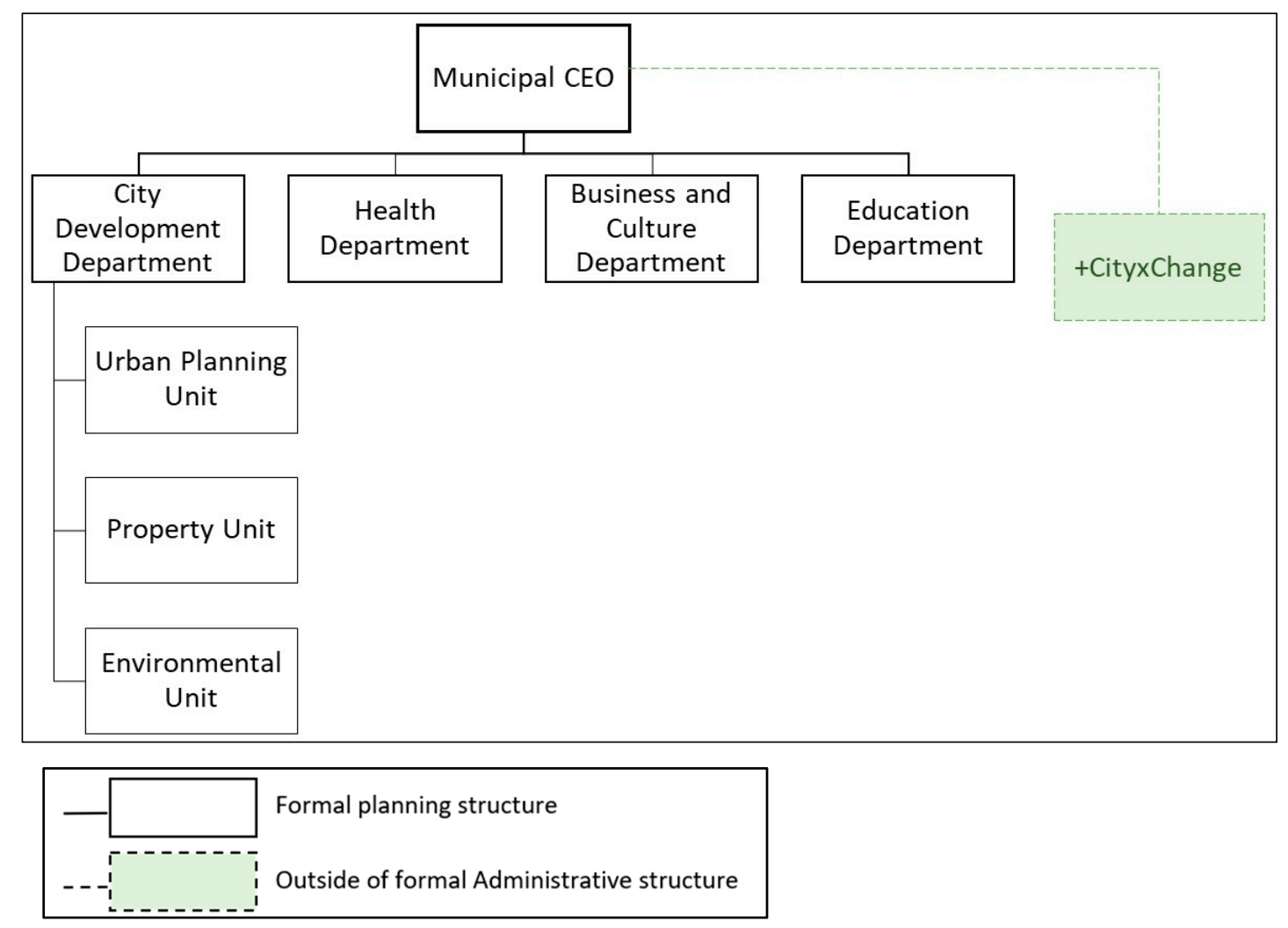

Figure 2. Position of + CityxChange within the formal municipal structure.

Therefore, the best possible way to get the fund was to anchor the project outside the formal structure, detaching it from the normal bureaucratic processes that would impose a political accountability to many stakeholders outside the project, including citizens. Correspondingly, the current position of the project could short-circuit the planning process by "leapfrogging formal planning stages or by sidestepping civil society involvement" [24] (p. 742).

Subsequently, citizens' formal participation rights in this project are limited to the phases after the approval of the proposal, only to designing and innovating solutions. This may partly explain citizen apathy and reluctance to participate in the later phases. When citizens' knowledge and input have not been included in the proposal, the question is how the proposal's quality can be ensured for designing an effective citizen participatory framework. The fact that the project is not anchored directly within the municipal administrative structure of urban development presents a challenge to the democratic legitimacy and effectiveness in the project. The dependency on competitive funding of EU has influenced the goal-setting of the project, in which the "by the people" element of participation, as a strong component behind the concept of the proposal, is missed. It is not surprising that implementing participatory democracy is challenging, when the proposal is drafted and agreed upon by some specific actors who would decide upon the influence and role of citizens beforehand. From the kick-off of the project, efforts have been made to conform citizens to this idea, without considering whether the project's proposed energy model or prosumerism is in line with citizens' own preferences and choices.

Figure 3 illustrates the lack of citizens' involvement and consideration of their needs and demands in the proposal phase. 


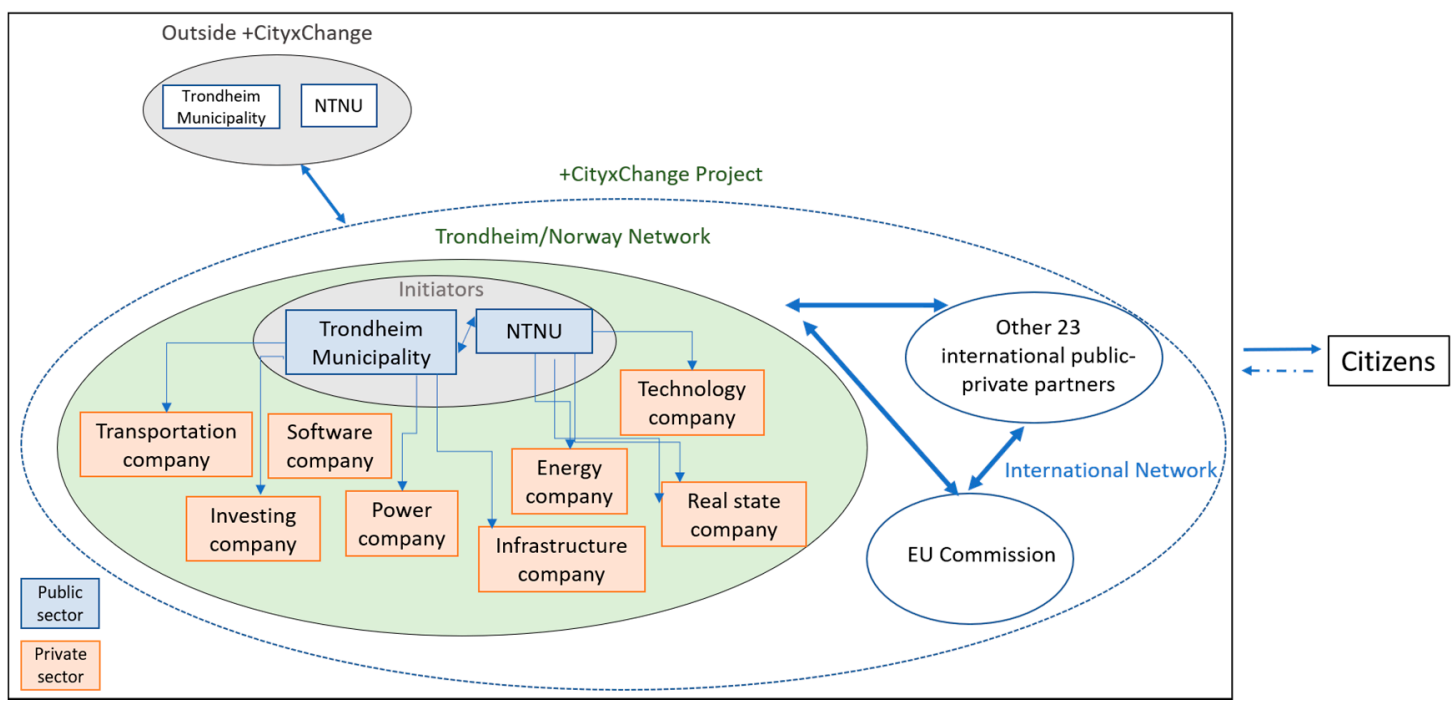

Figure 3. The governance network of +CityxChange in the initiation/proposal phase.

As Figure 3 shows, some specific actors within the public and private sectors in Norway have formed a collaboration with other international actors, to co-write an EU proposal. The +CityxChange project group has some (semi-)informal collaborations with other NTNU and Trondheim Municipality partners which are not officially part of the project. These two groups (within and outside the project) constitute a joint network in relation to citizens. Therefore, the formulation of the +CityxChange proposal in Trondheim was based on the closed negotiations of NTNU, Trondheim Municipality, and private actors on framing the problem, the content of the project, site-selection, and cost-sharing in development stages. The democratic problem arising from this situation is that these negotiations and agreements were closed to both citizens and their political representatives. Neither citizens nor politicians had any formal role or influence in the initiation or formulation phases of the project. This democratic problem is strengthened by the EU's approval of the project, which is binding on the politicians, even if they have not been formally involved. Thus, politicians are already squeezed between the conditions made by the initiators of these projects and the impact of the project that is in benefit of citizens, such as sustainability, creating positive energy districts, housing, and infrastructure [25]. In addition, a lack of transparency in the informal stage of negotiation between specific actors has also blurred the accountability of political institutions. In this regard, it is difficult for citizens to get a picture of whom to hold accountable for the results of initial agreements and negotiations, which may have major impacts on the final planning decisions.

After the project was kicked off, the local partners used different forum (such as internal and external conferences and workshops, expo, exhibitions, and joint-project events) and resources (including the project budget), formally and informally, to introduce, discuss, and communicate the project's objectives with other local stakeholders, and to fulfil the predetermined milestones and deliverables of the contract.

"+CityxChange aims at linking the changes that was mandated by EU, such as transition of the energy system toward renewable energy or changing human behavior in a sustainable way, with the existing city strategies. We want to understand how the city is able to adapt to these new circumstances and make the best use of those" (I5).

According to the proposal of the project, through co-creative and innovative governance, a bold city vision should be developed that puts the public interest in front and center. On the one hand, there is no space for citizens to reframe the initiative around their concerns and desires in practice. On the other hand, the current collaboration between different actors, within and beyond the project, becomes a governance and project-management challenge that can result in the instrumental and paternalistic strategies. In the present situation, the output-oriented approach of the call and the project framework, 
focusing on effective problem-solving rather than strong democracy (input-oriented legitimacy), has resulted in conflicting understandings and strategies amongst partners that hinder effective citizen participation. As both an input and output legitimacy are necessary for democratic legitimization [23], it is unclear how local stakeholders can act to demonstrate their approach toward input-oriented legitimacy, i.e., enabling citizens' preferences to influence final solutions, and simultaneously react to the EU's output-oriented approach is a crossroad to handle. As we discussed in Section 2, the input legitimacy that should be insured by the political representative is challenged due to the institutional and constructive limitations of EU projects. Such limitations imply not only a lack of majoritarian institutional inputs (direct elections for a government) but also of a collective identity or European demos [60].

While none of the main actors of the project, including the municipality, raised the "of people" mechanisms, all three of the interviewed citizens explicitly referred to it:

"Usually people use a volunteer organization, called 'Velforening' in a private housing area, or board, called 'styre' within a corporate housing area (borettslag), to deliver their opinion to the municipality. Velforening or board does not have any legal authority but if many people join it and become active, it will have a power" (I8).

"The point is that it is better to deliver our opinion as a community group, since the opinion from a single person sometimes is not heard" (I9).

"People can use two channels to deliver their opinion: 1. through the politicians and 2. through the municipality's administrative. The former can be more effective because politicians' position depends on people's election" (I10).

In order to ensure democratic legitimacy, the reasons for making a decision must be justified to those that are affected by them [61]. However, due to the lack of appropriate (formal) framework, there is no arena, e.g., public meetings or media, in which +CityxChange objectives can be presented and discussed with citizens. According to our interviews with both the key actors and citizens, the newspaper is the main channel to hear and be heard. However, the newspaper cannot replace the information needed to ensure equal opportunities for citizens to provide input in an informed manner. For instance, it does not provide an accessible archive in which people can easily find the desired information. At the same time, the web-based channels, such as the official website of +CityxChange, are not well-known to citizens and are not adapted so that citizens can understand what the project means to their neighborhoods or lifestyle.

The novelty of smart city initiatives and European lighthouse city projects in general, as well as the lack of a united method, framework, information, and deliberative arena for it, has increased the underlying ambiguities, inconsistent interpretations, and misunderstandings amongst project partners that reflect upon their practices and approach.

Moreover, the institutional setup of +CityxChange outside the formal administrative urban planning structure is accompanied by a series of other challenges, which are categorized under three headings:

I. Crossover roles and challenges of representing several interests at the same time

Within the current governance network (Figure 3), each stakeholder can have simultaneously diverse roles due to their individual collaborations in various projects, representing different institutions, and thus carrying several identities or social roles in different sectors (state, market, community, and third sector) simultaneously. For example, a policymaker (state) is also a neighbor (community), consumer (market), and possibly a volunteer in his free time (third sector) [62]. In addition to the sector's role, people have an organizational role (e.g., leader, accountant, planner, researcher, etc.) and individual role (e.g., mother, vegetarian, etc.) that can also shift over time. On the other hand, each stakeholder can have simultaneously diverse organizational roles, representing different institutions' logics and values. For instance, while the project developer of the +CityxChange is only affiliated with one specific institution, he/she has to represent the EU's and other partner institutions' interests at the 
same time. In addition, while some partners have strategic roles in the project and are accountable for participation, they are partially employed by both a university and municipality, representing two diverse collective interests and strategies. Many partners that are involved in the project but work at Trondheim Municipality or NTNU are affiliated with different departments, which in turn have different values, perspectives, interests, and/or agendas, and it is not easy to understand their approaches and align with their practices. Therefore, crossover roles, resulting from institutional structure of the project, have influenced the partners' approaches. Accordingly, the participatory practices depend on practitioners' different sector and institutional logics and their different roles.

Even though interviewees' responses many times indicate that their actions would or should target citizens (see Table 3), when we directly asked them who the main target groups are, none of the project partners mentioned citizens. We can explain such contradictions in two ways: (1) as the methodological challenge and (2) as the complexity of understanding citizens as one group. Regarding the former, the informants may unconsciously modify their responses. It is natural that they try to answer in a selective way that fits them more comfortably into the positive point of view toward citizen participation. The informants may feel that the affairs of their organization, the project, or their own personal life (because they are citizens themselves) should be put forward in light of the participatory approach. Subsequently, they may hesitate to bring up their real perspectives [63]. The latter point refers to the certain conceptual vagueness of the "citizen" concept, which usually refers to a generalized category of people. However, in practice, citizens can refer to a diverse and pluralistic group of people with different and usually contrasting interests. Our interviews with citizens show such complexity:

"The people who are going to live in the project's demonstration areas are not usually those that are invited to the meetings, because they have not decided to live there yet. So, the opinion is not based on the needs of people who are going to live there but the people who are disturbed by the development of the area" (I9).

The statement above can imply the next challenge.

\section{Contrasting time horizons}

Our findings also showed that in addition to different perspectives, actors have different time horizons. While urban development and people outside of +CityxChange (Figure 3) have a long-term horizon to pragmatically balance multiple needs, the EU program and +CityxChange network have a short-term horizon, endeavoring for fast and effective solutions and processes. While different planners and researchers in the municipality and university collaborate to develop a new participatory framework for citizens, those that are affiliated within the project have a five-year deadline. However, people outside the project have an extended and highly unpredictable time horizon. Another example is the increasing concern for improving the physical environment that requires more long-term planning and consideration, whereas a recent statutory rule of time limits for handling +CityxChange demands shorter temporal horizons and tighter temporal controls. The prevailing mismatch between their time orientations and horizons has challenged the efficiency of their approaches and practices. Indeed, such a challenge might be regarded as a favoring of developers' interests. Therefore, institution of actors and resources to leverage toward specific aims, which is often static, needs continuous adjustment and improvement, due to the different timeframes of goals and the corresponding complexities $[6,64]$.

\section{Lack of appropriate methodological and ideological framework for citizen participation}

Even though the project partners may have complementary approaches toward participatory and deliberative democracy, there is no clarity on shared understanding and consensus on approaches and practices regarding the "for" people, "of" people, and "by" people aspects. There is no structured framework or roadmap to guide them and make them responsible and accountable for their actions. Furthermore, there is no consensus on the citizen-participation approach to clarify why participation is needed (which type of legitimacy), who the target groups are, and how and to what extent their engagement should be facilitated. Different actors have tried different participatory techniques and 
strategies. However, these practices are usually done independently, and no appropriate interconnection between them exists. Accordingly, one of the parallel goals of the municipality is to use +CityxChange or smart strategies (open data) to merge all the single activities together.

We argue that the lack of an ideological framework or lens for dealing with participatory practices can obscure the main actors' awareness of their own approach toward citizenship and hinder their ability to evaluate or reflect on their own values. This can partly relate to the fact that practitioners do not rely on or benefit from a theoretical framework. For example, the scaffold of participation presented in this paper is a helpful point of departure for researchers but is usually of no practical use to practitioners and authorities. Accordingly, we believe that the current project is only able to reach output legitimacy (if it will be successful) by acting on behalf of, and bringing benefits to, citizens.

To conclude, the institutional structure of +CityxChange outside the formal administrative planning framework and the corresponding three functional barriers have resulted in a mismatch between the prevailing participatory approaches and practices that Figure 4 shows.

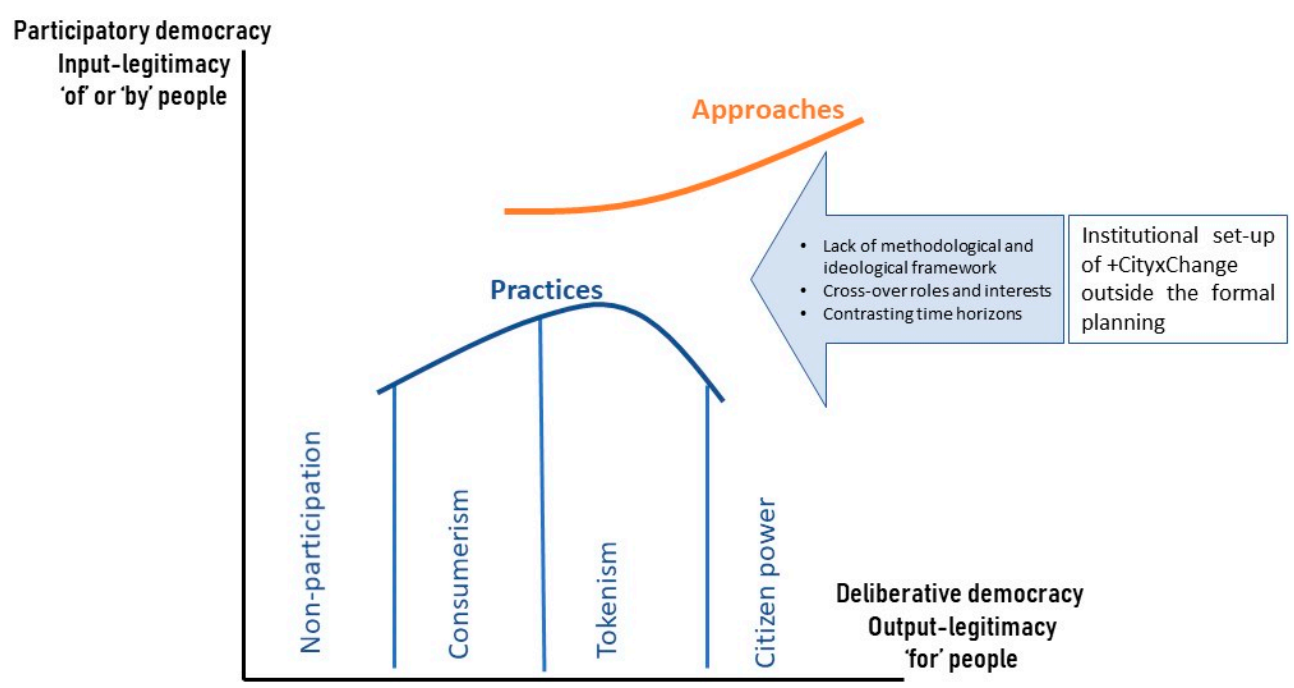

Figure 4. A mismatch between prevailing approaches and practices and the influential structural-functional factors within +CityxChange.

\section{Suggestions}

We have argued that the intention and success of participation is very much dependent on "the eye of the beholder" [18] (p. 252). Main actors' approaches toward the role of citizens can affect and transform the citizens' view and willingness to participate, especially when they realize that their contribution is necessary to transform a survival city to a livable and attractive city. Therefore, we believe that city authorities should clarify and be aware of all the existing democratic visions and strategies that exist within and beyond the pilot project. While the main actors' efforts in +CityxChange go toward developing a framework and guideline for participation, we argue and suggest the necessity of deliberation on the following:

- The nature of citizen participation in relation to democratic legitimacy and accountability, including clarifying why participation is needed (which type of legitimacy);

- The appropriate target groups;

- How and to what extent citizen engagement should be facilitated, and by whom;

- The appropriate time horizon;

- The roles that citizens and authorities should play in different planning stages, to provide a dynamic intermingling of ideas and sharing of understanding between authorities and citizens.

For example, a process where the goal is to increase the use of public transportation for diverse groups of society is different from a situation where one needs input on energy-consumption patterns. 
In the former, the "citizen control" or "delegated power" categories of Arnstein are more feasible, while in the latter, "informing" and "consultation" may be more reasonable. On the other hand, the form of citizen participation in different projects, as well as different phases of planning and decision-making, can and should vary. While it is important that people can be directly involved in the initiation phases, being empowered to invent or claim the deliberative processes with other stakeholders, they should be able to trust their representatives and assign the necessary responsibility and tasks to them in the implementation phases, consenting to the information and consultation. In addition, a project that aims at developing an innovative technical solution (output-oriented) (e.g., in which citizens are the end-users of services, the public authorities are facilitators and enablers, and private sectors are the initiators) requires a different type of citizen participation than a project that aims at solving an issue raised up by people (e.g., in which the public authorities are only collectors and interpreters of citizens' experiences that are responsible to transform their demands into professional practices).

In our opinion, if citizens can have a dynamic and open platform, in which they can permanently and continuously have a chance to express their concerns and ambitions directly or through their community representatives, we will have both democratic and effective processes. Our argument is that there should be a platform that can provide a dynamic intermingling of ideas and sharing of understanding between authorities and citizens. It is ineffective to go to the midst of lay people, seeking ideas and information, but they have transparent and constant opportunities to decide upon their direct or indirect participation. As our interviewees suggested, their indirect participation should be through an empowered community representative (e.g., a neighborhood organization (velforening)) who will have shared values, interests, and needs with the community, as these are different from political representatives, who only have shared political ideologies [28]. In this regard, there is no need for their direct participation all the time and in all phases of planning, which can also ensure efficiency, particularly in time-intensive projects. However, this requires the empowerment and formal institutionalization of their community representatives in the urban-planning structure. The enactment of community representatives at the local level can thus create urgency for the introduction of indirect "of people" participation that is in alignment with the "by people" and "for people" mechanisms. Based on this argument, and while citizens are informed and agree on goals, strategies, and their own and authorities' roles and processes, we will not have classification of non-participation to citizen power (see Arnstein's ladder of participation). If people consent that they would like to act as a proposer or recipient, then there will be no tokenism. In this regard, our suggestion is that, instead of developing a general framework, the focus should be on empowering and positioning the community representative within the formal planning and deliberative governance system. In Table 4, we recall our research questions, summarize our findings, and suggest some of the possible solutions.

Table 4. Summary of findings and corresponding suggestions.

\begin{tabular}{|c|c|c|}
\hline \multirow[t]{2}{*}{ Research Questions } & \multicolumn{2}{|c|}{ Answers } \\
\hline & Approaches & Practices \\
\hline $\begin{array}{l}\text { What are the prevailing } \\
\text { approaches, understandings, } \\
\text { and practices in relation to } \\
\text { citizen participation amongst } \\
\text { the key actors involved in } \\
\text { +CityxChange? }\end{array}$ & $\begin{array}{l}\text { - Most of the partners at the university } \\
\text { and municipality have a complementary } \\
\text { approach, aiming not only at giving } \\
\text { actual decision-making power to } \\
\text { citizens ("by" people), but also at } \\
\text { effectiveness of the policy outcomes } \\
\text { ("for" the people). } \\
\text { - The private sector has been more } \\
\text { output-efficiency oriented, aiming at } \\
\text { using technology to change behaviors or } \\
\text { attitudes of citizens/users, for better } \\
\text { unitization of services ("for" people). } \\
\text { - The citizens are more mindful about } \\
\text { the role and power of their } \\
\text { representatives ("of" people). }\end{array}$ & $\begin{array}{l}\text { The prevailing practices are more } \\
\text { instrumental and paternalistic rather } \\
\text { than normative or political. } \\
\text { Additionally, citizens have to perform } \\
\text { within the bounds of expected and } \\
\text { acceptable behavior, and they cannot } \\
\text { transgress or resist any of the project's } \\
\text { social and political norms. Citizens are } \\
\text { steered, controlled, and nudged to act in } \\
\text { certain ways, being treated as } \\
\text { consumers, testers, or sources of data. } \\
\text { Therefore, the actors' practices do not } \\
\text { match their approaches and do not go } \\
\text { higher than "information" or } \\
\text { "consultation" of "tokenism". }\end{array}$ \\
\hline
\end{tabular}


Table 4. Cont.

\begin{tabular}{cc}
\hline $\begin{array}{c}\text { Which structures and processes } \\
\text { have influenced the prevailing } \\
\text { approaches and practices? }\end{array}$ & $\begin{array}{c}\text { The institutional structure of +CityxChange outside the formal administrative } \\
\text { planning, which has resulted in following functional barriers: }\end{array}$ \\
$\begin{array}{c}\text { I. Crossover roles and challenges of representing several interests at the same time; } \\
\text { II. Contrasting time horizons; }\end{array}$ \\
III. Lack of appropriate methodological and ideological framework. \\
Recommendation \\
- Actors need to understand and agree on the nature of the participatory or \\
deliberative democracy, clarifying why participation is needed (which type of \\
legitimacy), who the target groups are, how and to what extent citizen engagement \\
should be facilitated, in which time horizon, and how their own roles fit. \\
- Existence of a dynamic and open platform for intermingling of ideas and sharing \\
of understanding between authorities and citizens. \\
- Benefiting indirect participation through empowerment and formal \\
institutionalization of citizens' community representatives in urban planning and \\
deliberative governance system.
\end{tabular}

\section{Conclusions}

Through the lens of input legitimacy, participatory democracy, and direct ("by" or "of" people) participation versus output legitimacy, deliberative democracy, and indirect ("for" people) participation, this paper has attempted to explore the prevailing approaches and practices in the smart city project + CityxChange. The scaffold of smart citizen participation, a developed framework of Arnstein's ladder of participation, was used for assessing the key local partners' approaches and practices. Our research has shown that there is a mismatch between the key actors' participatory approaches and practices.

The university and municipality have aimed to exploit the project for co-creating an overarching framework, which can increase the power and influence of citizens. Despite the complementary approaches of the university and municipality toward ensuring democratic legitimacy, their prevailing practices are more instrumental rather than normative or political. The paper investigated the structures and functions that inhibit the democratic legitimacy of citizen participation in +CityxChange. The institutional structure of EU projects, such as +CityxChange, confined the practices of these local authorities to "tokenism" and directed perceptions of the citizen as a customer. The legal and financial anchorage of +CityxChange, outside the formal administrative planning structure, is seen in line of the neoliberalism in Norway and Europe, in general. The neoliberal ideology and the subsequent smart city projects have caused technical, political, and economic goals to surpass social and environmental goals. Thus, it is difficult to estimate to what extent existing smart city processes or projects can keep up with a city's original expectations and ideals, such as enhanced citizen participation [65]. The dependency on competitive funding of the EU has influenced the goal-setting of the project, in which neither citizens nor their representatives engaged. Indeed, the proposal was drafted and agreed among by some specific actors who decided upon the citizens' influence and actions, and participatory processes beforehand. Thus, +CityxChange is designed in a way that citizens are encouraged to help in providing solutions, to give feedback, or to perform certain roles. Citizens do not have an opportunity to challenge or replace the fundamental political rationalities or voluntarily shape their own plan. This triggers a question as to where citizens' input will be formalized or held accountable. It implies an orientation toward "output legitimacy" and the top-down functionality of EU projects, in which only a selected group of people (can) co-write the application in response to the EU's predetermined objectives. Therefore, the citizen-centric approach of +CityxChange, in practice, leaves no room for citizens' influence. An emphasis on creating innovative solutions in partnership with the private sector and a focus on efficiency has disturbed the long-term horizon of urban planning and democratic legitimacy, which are both resource and time demanding. Within such an output-oriented approach, citizen participation has only become a process of formal compliance with the expectations of the external environment (e.g., EU). This has unintentionally caused a disconnection between the external image and the actual public participation in +CityxChange [40]. Correspondingly, citizens still are not delegated to challenge or replace the fundamental political rationalities shaping an issue or 
plan [9]. Therefore, the institutional structure of the project has inhibited democratic legitimacy and intensified the preexisting complexity of urban planning, rather than facilitating them. In addition, it has resulted in some other functional barriers, which we divide into three categories: (I) crossover roles and challenges of representing several interests at the same time; (II) contrasting time horizons and orientations; and (III) the lack of an appropriate ideological and methodological framework.

To conclude, our paper emphasizes that there is no specific structural or functional factor that inhibits citizen participation. On the contrary, the combination and interaction of different interdependent factors have led to such an outcome. We believe that the smart city concept has emerged as a result of the neoliberal political trend, in which the invisible hand of the market is supposed to not only ensure an optimal allocation of private goods but also to regulate the public goods' production more efficiently. However, the increased reliance on market/business forces has been criticized for throwing weight behind power and money, and thus undermining the social bonds and virtues of civil society [43]. Therefore, the citizen-centric smart city ideal has emerged to silence detractors of high-tech business-led smart cities. In order to keep the central mission of capital accumulation and top-down or technocratic governance intact, but also advocate a citizen-centric approach, applicants of EU research projects must underline both technical and participatory aspects (such as co-design and co-creation). Accordingly, in projects with a focus on energy-saving solutions (such as +CityxChange), the participation of citizens is indeed marginal in the project design phase, while essential to achieve some results. Therefore, using time and resources to increase the role and power of citizens has nothing to do with the idea of the smart city that is strictly linked with the standard funding scheme of the EU. Indeed, it should be an integral part of any planning and decision-making processes and not necessarily just the smart ones.

Therefore, city planners and decision-makers need to clarify and communicate their approaches to the problem, intervention methods, available resources, and possible decisional procedures. In addition, they have to identify why (goals), how, and by what means they will reach their participatory visions. If citizens can have constant deliberation with the main actors, it is not necessary for them to be directly involved in all processes, as information-sharing, knowledge-access, and equality are also parts of democratization. They can discuss and agree on the scope of participation, whether citizens' roles are as "consumers/end-users" or "residents". Subsequently, they need to specify which levels of participation fit the goals and approaches (output-oriented or input-oriented). This can also be achieved if citizens have representatives whom they can trust and rely on to advocate for them, while at the same time ensuring the efficiency of the decision-making process. In order to foster "citizen power" in the longer term and thereby strengthen a strong democracy, we recommend that city planners and authorities find a way to align the informal structure of participation in pilots with formal regulatory structures. Moreover, external board evaluation or research on the quality of participation in the three levels of "by, of, and for" people, in practice, may be helpful to assess democratic values, such as community-building, trust, representation, efficiency, and influence. Further research is also valuable, to extend or compare the findings of this research with other smart city projects that are developed within the formal planning system [65].

Author Contributions: Conceptualization, S.G., B.F.N., and D.B.; methodology, W.Z.S., B.F.N., S.G., and D.B.; validation, B.F.N.; formal analysis, S.G., B.F.N., and D.B.; writing-original draft preparation, S.G., D.B., B.F.N. and E.G.; writing-review and editing, S.G., B.F.N., D.B, E.G., and W.Z.S.; visualization, S.G., D.B., B.F.N., and E.G.; supervision, S.G. All authors have read and agreed to the published version of the manuscript.

Funding: This research received no external funding.

Acknowledgments: We would like to express our thanks to the reviewers and the academic editors for their guidance, time, and input that they have given us, as well as their contributions to raising the overall quality of the paper. We would like to thank Bradley Loewen from the Norwegian University of Science and Technology for useful comments and English editing. We also gratefully acknowledge several partners through the research project Planning Instruments for Smart Energy Communities (PI-SEC) and the Research Centre on Zero Emission Neighbourhoods in Smart Cities (FME ZEN), both funded by the Norwegian Research Council and partners. We also thank the participants from the +CityxChange project, NTNU, and Trondheim Municipality. 
Conflicts of Interest: The authors declare no conflict of interest.

\section{References}

1. Russo, F.; Rindone, C.; Panuccio, P. The process of smart city definition at an EU level. WIT Trans. Ecol. Environ. 2014, 191, 979-989.

2. European Commission. Leading the Way in Making Europe's Cities Smarter-Frequently Asked Questions. 26.11 ed.; European Commission. 2013. Available online: https://ec.europa.eu/digital-single-market/en/news/ leading-way-making-europes-cities-smarter---frequently-asked-questions (accessed on 18 April 2020).

3. European Commission. Horizon 2020 - Work Programme 2018-2020; Secure, Clean and Efficient Energy 25.03 ed.; European Commission. 2020, pp. 1-318. Available online: https:/ec.europa.eu/research/participants/ data/ref/h2020/wp/2018-2020/main/h2020-wp1820-energy_en.pdf (accessed on 18 April 2020).

4. +CityxChange. What Is a Smart City? +CityxChange. 2019. Available online: https://cityxchange.eu/ (accessed on 18 April 2020).

5. Giffinger, R.; Fertner, C.; Kramar, H.; Meijers, E. City-ranking of European medium-sized cities. Cent. Reg. Sci. Vienna UT 2007, 1-12. Available online: http://www.smartcity-ranking.eu/download/city_ranking_final.pdf (accessed on 18 April 2020).

6. Schaffers, H.; Komninos, N.; Pallot, M.; Trousse, B.; Nilsson, M.; Oliveira, A. Smart cities and the future internet: Towards cooperation frameworks for open innovation. In The Future Internet Assembly; Springer: Berlin/Heidelberg, Germany, 2011; pp. 431-446.

7. Komninos, N.; Pallot, M.; Schaffers, H. Special issue on smart cities and the future internet in Europe. J. Knowl. Econ. 2013, 4, 119-134. [CrossRef]

8. Greenfield, A. Against the Smart City: A Pamphlet. This Is Part I of "The City Is Here to Use"; Do projects: New York, NY, USA, 2013.

9. Cardullo, P.; Kitchin, R. Being a 'citizen' in the smart city: Up and down the scaffold of smart citizen participation in Dublin, Ireland. GeoJournal 2019, 84, 1-13. [CrossRef]

10. Joss, S.; Cook, M.; Dayot, Y. Smart cities: Towards a new citizenship regime? A discourse analysis of the British smart city standard. J. Urban Technol. 2017, 24, 29-49. [CrossRef]

11. Pimbert, M.; Wakeford, T. Deliberative Democracy and Citizen Empowerment; PLA Notes; International Institute for Environment and Development (IIED): London, UK, 2001; pp. 23-28.

12. Nam, T.; Pardo, T.A. Smart city as urban innovation: Focusing on management, policy, and context. In Proceedings of the 5th International Conference on Theory and Practice of Electronic Governance, Tallinn, Estonia, 26-28 October 2011; pp. 185-194. [CrossRef]

13. Burby, R.J. Making plans that matter: Citizen involvement and government action. J. Am. Plan. Assoc. 2003, 69, 33-49. [CrossRef]

14. Van Herzele, A. Local knowledge in action: Valuing nonprofessional reasoning in the planning process. J. Plan. Educ. Res. 2004, 24, 197-212. [CrossRef]

15. Brabham, D.C. Crowdsourcing the public participation process for planning projects. Plan. Theory 2009, 8 , 242-262. [CrossRef]

16. Salaj Alenka, T.; Roumboutsos, A.; Verlič, P.; Grum, B. Land value capture strategies in PPP—What can FM learn from it? Facilities 2018, 36, 24-36. [CrossRef]

17. Halachmi, A.; Holzer, M. Citizen participation and performance measurement: Operationalizing democracy through better accountability. Public Adm. Q. 2010, 34, 378-399.

18. Willems, J.; Van den Bergh, J.; Viaene, S. Smart City Projects and Citizen Participation: The Case of London. In Public Sector Management in a Globalized World; Andeßner, R., Greiling, D., Vogel, R., Eds.; Springer Fachmedien Wiesbaden: Wiesbaden, Germany, 2017; pp. 249-266. [CrossRef]

19. Nielsen, B.F.; Baer, D.; Lindkvist, C. Identifying and supporting exploratory and exploitative models of innovation in municipal urban planning; key challenges from seven Norwegian energy ambitious neighborhood pilots. Technol. Forecast. Soc. Chang. 2019, 142, 142-153. [CrossRef]

20. Day, D. Citizen participation in the planning process: An essentially contested concept? J. Plan. Lit. 1997, 11, 421-434. [CrossRef]

21. Lund, D.H. Co-creation in urban governance: From inclusion to innovation. Scand. J. Public Adm. 2018, 22, 3-17. 
22. Floridia, A. From Participation to Deliberation: A Critical Genealogy of Deliberative Democracy; ECPR Press: Colchester, UK, 2017.

23. Scharpf, F.W. Governing in Europe: Effective and Democratic?; Oxford University Press: New York, NY, USA, 1999.

24. Schmidt, V.A. Democracy and legitimacy in the European Union revisited: Input, output and 'throughput'. Political Stud. 2013, 61, 2-22. [CrossRef]

25. Falleth, E.I.; Hanssen, G.S.; Saglie, I.L. Challenges to democracy in market-oriented urban planning in Norway. Eur. Plan. Stud. 2010, 18, 737-753. [CrossRef]

26. Halpin, D.R. The participatory and democratic potential and practice of interest groups: Between solidarity and representation. Public Adm. 2006, 84, 919-940. [CrossRef]

27. Osborne, S.P. Public Management: Policy Making, Ethics and Accountability in Public Management; Taylor \& Francis: London, UK; New York, NY, USA, 2002; Volume 5.

28. Wagle, $\mathrm{U}$. The policy science of democracy: The issues of methodology and citizen participation. Policy Sci. 2000, 33, 207-223. [CrossRef]

29. Chambers, E. The cultures of science and policy. In Policy Analysis: Perspectives, Concepts, and Methods; Dunn, W.N., Ed.; JAI Press: Greenwich, CT, USA, 1986; pp. 93-110.

30. Schneider, A.; Ingram, H. Social Construction of Target Populations: Implications for Politics and Policy. Am. Political Sci. Rev. 1993, 87, 334-347. [CrossRef]

31. Schneider, A.L.; Ingram, H.; DeLeon, P. Democratic policy design: Social construction of target populations. Theor. Policy Process 2014, 3, 105-149.

32. Boedeltje, M.M.; Cornips, J.J. Input and Output Legitimacy in Interactive Governance; NIG Annual Work Conference 2004 Rotterdam. 2004. Available online: http://hdl.handle.net/1765/1750 (accessed on 18 April 2020).

33. Dahl, R.A. On political Equality; Yale University Press: New Haven, CT, USA; London, UK, 2006.

34. Innes, J.E.; Booher, D.E. Planning with Complexity: An Introduction to Collaborative Rationality for Public Policy; Routledge: London, UK; New York, NY, USA, 2010.

35. Perrow, C. Complex Organizations: A Critical Essay; Scott, Foresman: Glenview, IL, USA, 1972.

36. Nyseth, T. Network governance in contested urban landscapes. Plan. Theory Pract. 2008, 9, 497-514. [CrossRef]

37. Arnstein, S. A Ladder of Citizen Participation. In The City Reader; LeGates, R.T., Stout, F., Eds.; Routledge: London, UK, 1996; pp. 238-251.

38. Refstie, H.; Brun, C. Voicing noise: Political agency and the trialectics of participation in urban Malawi. Geoforum 2016, 74, 136-146. [CrossRef]

39. Poulsen, B. Competing traditions of governance and dilemmas of administrative accountability: The case of Denmark. Public Adm. 2009, 87, 117-131. [CrossRef]

40. Yetano, A.; Royo, S.; Acerete, B. What is driving the increasing presence of citizen participation initiatives? Environ. Plan. C Gov. Policy 2010, 28, 783-802. [CrossRef]

41. Lindblom, C.E.; Woodhouse, E.J. The Policy-Making Process, 3rd ed.; Prentice Hall: Englewood Cliffs, NJ, USA, 1993.

42. Potts, R.; Vella, K.; Dale, A.; Sipe, N. Exploring the usefulness of structural-functional approaches to analyse governance of planning systems. Plan. Theory 2014, 15, 162-189. [CrossRef]

43. Gohari, S. Governance in the Planning and Decision-Making Process: The Co-Location Case of University Campuses in Trondheim, Norway [2000-2013]; Norwegian University of Science and Technology, Faculty of Architecture and Design, Department of Architecture and Planning: Trondheim, Norway, 2019; Volume 74.

44. Forester, J. Planning in the Face of Power; University of California Press: Berkeley, CA, USA, 1989. Available online: https://www.tandfonline.com/doi/abs/10.1080/01944368208976167 (accessed on 18 April 2020).

45. Dente, B. Who Decides? Actors and Their Resources. In Understanding Policy Decisions; Springer: Berlin, Germany, 2014; pp. 29-66.

46. Fiskaa, H. Past and future for public participation in Norwegian physical planning. Eur. Plan. Stud. 2005, 13, 157-174. [CrossRef]

47. Creswell, J.W. Educational Research: Planning, Conducting, and Evaluating Quantitative, 3rd ed.; Pearson Prentice Hall: Upper Saddle River, NJ, USA, 2008.

48. Potter, W.J. An Analysis of Thinking and Research about Qualitative Methods; Routledge: Abingdon, UK, 2013. 
49. Yin, R.K. Applications of Case Study Research; SAGE: Los Angeles, CA, USA, 2012; p. XXXI.

50. Gbikpi, B.; Grote, J.R. From democratic government to participatory governance. In Participatory Governance; Springer: Berlin, Germany, 2002; pp. 17-34.

51. Commission, E. Horizon 2020 Work Programme 2016-2017. Cross-Cutting Activities (Focus Areas) European Commission. 2016. Available online: https:/ec.europa.eu/research/participants/data/ref/h2020/wp/2016_ 2017/ (accessed on 18 April 2020).

52. +CityxChange. Team. +CityxChange. 2019. Available online: https://cityxchange.eu/team/ (accessed on 18 April 2020).

53. +CityxChange. Objectives. +CityxChange. 2019. Available online: https://cityxchange.eu/objectives/ (accessed on 18 April 2020).

54. Kemmis, S.; McTaggart, R.; Nixon, R. Introducing critical participatory action research. In The Action Research Planner; Springer: Berlin, Germany, 2014; pp. 1-31.

55. Kidd, S.A.; Kral, M.J. Practicing participatory action research. J. Couns. Psychol. 2005, 52, 187. [CrossRef]

56. Denscombe, M. The Good Research Guide: For Small-scale Social Research Projects; Open University Press: Buckingham, UK, 1998.

57. Trochim, W.M.K. Qualitative measures. Res. Meas. Knowl. Base 2006, 361-9433.

58. Radu, V. Qualitative Research: Definition, Methodology, Limitation, Examples. 03.04 ed. 2019. Available online: https://www.omniconvert.com/blog/qualitative-research-definition-methodologylimitation-examples.html (accessed on 18 April 2020).

59. Trevino, L.K. Ethical Decision Making in Organizations: A Person-Situation Interactionist Model. Acad. Manag. Rev. 1986, 11, 601-617. [CrossRef]

60. Cardullo, P.; Kitchin, R. Smart urbanism and smart citizenship: The neoliberal logic of 'citizen-focused'smart cities in Europe. Environ. Plan. C Politics Space 2019, 37, 813-830. [CrossRef]

61. King, L.A. Deliberation, legitimacy, and multilateral democracy. Governance 2003, 16, 23-50. [CrossRef]

62. Avelino, F.; Wittmayer, J.M. Shifting power relations in sustainability transitions: A multi-actor perspective. J. Environ. Policy Plan. 2016, 18, 628-649. [CrossRef]

63. Dean, J.; Whyte, W. How Do You Know If the Informant is Telling the Truth? Hum. Organ. 1958, 17, 34-38. [CrossRef]

64. Bifulco, F.; Tregua, M.; Amitrano, C.C. Co-governing smart cities through living labs. Top evidences from EU. Transylv. Rev. Adm. Sci. 2017, 13, 21-37. [CrossRef]

65. Gohari, S.; Ahlers, D.; Nielsen, B.F.; Junker, E. The Governance Approach of Smart City Initiatives. Evidence from Trondheim, Bergen, and Bodø. Infrastructures 2020, 5, 31. [CrossRef] 